San Jose State University

SJSU ScholarWorks

Master's Theses

Master's Theses and Graduate Research

1991

\title{
Spring foraging of Sanderling (Calidris alba) in response to aggregations of Emerita analoga Megalopae
}

Veronica B. Estelle

San Jose State University

Follow this and additional works at: https://scholarworks.sjsu.edu/etd_theses

\section{Recommended Citation}

Estelle, Veronica B., "Spring foraging of Sanderling (Calidris alba) in response to aggregations of Emerita analoga Megalopae" (1991). Master's Theses. 189.

DOI: https://doi.org/10.31979/etd.t9ba-xved

https://scholarworks.sjsu.edu/etd_theses/189

This Thesis is brought to you for free and open access by the Master's Theses and Graduate Research at SJSU ScholarWorks. It has been accepted for inclusion in Master's Theses by an authorized administrator of SJSU ScholarWorks. For more information, please contact scholarworks@sjsu.edu. 


\section{INEORMATION TO USERS}

This manuscript has been reproduced from the microfilm master. UMI films the text directly from the original or copy submitted. Thus, some thesis and dissertation copies are in typewriter face, while others may be from any type of computer printer.

The quality of this reproduction is dependent upon the quality of the copy submitted. Broken or indistinct print, colored or poor quality illustrations and photographs, print bleedthrough, substandard margins, and improper alignment can adversely affect reproduction.

In the unlikely event that the author did not send UMI a complete manuscript and there are missing pages, these will be noted. Also, if unauthorized copyright material had to be removed, a note will indicate the deletion.

Oversize materials (e.g., maps, drawings, charts) are reproduced by sectioning the original, beginning at the upper left-hand corner and continuing from left to right in equal sections with small overlaps. Each original is also photographed in one exposure and is included in reduced form at the back of the book.

Photographs included in the original manuscript have been reproduced xerographically in this copy. Higher quality 6" $\times 9$ " black and white photographic prints are available for any photographs or illustrations appearing in this copy for an additional charge. Contact UMI directly to order.

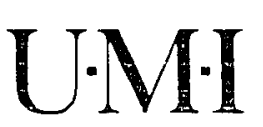

University Microlims internationai

A Bell \& Howell Information Company 300 North Zeeb Road. Ann Arbor, MI 48106-1346 USA

$313.761-4700 \quad 800521.0600$ 

Order Number 1945796

Spring foraging of sanderling (Calidris alba) in response to aggregations of Emerita analoga megalopae

Estelle, Veronica B., M.S.

San Jose State University, 1991

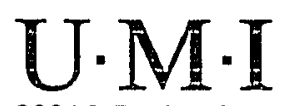

300 N. Zeeb Rd.

Ann Arbor, MII 48106 

Spring Foraging of Sanderling (Calidris alba)

in Response to Aggregations of Emerita analoga Megalopae

\author{
A Thesis \\ Presented to \\ The Faculty of Moss Landing Marine Laboratories \\ San Jose State University
}

In Partial Fulfillment

of the Requirements for the Degree

Master of Science

By

Veronica B. Estelle

August, 1991 
APPROVED FOR MOSS LANDING MARINE LABORATORIES

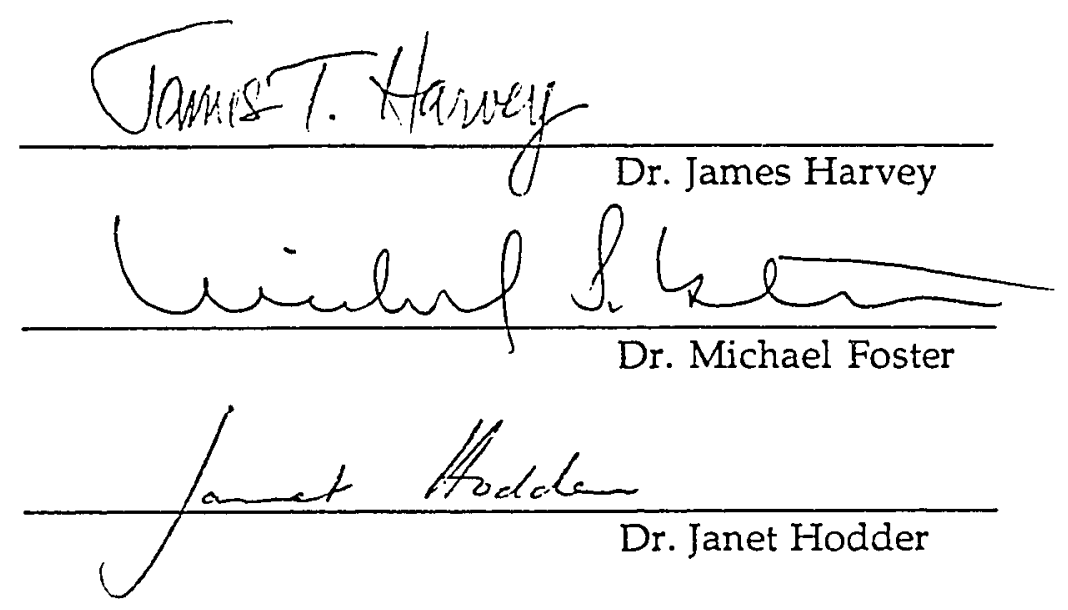

APPROVED FOR THE UNIVERSITY

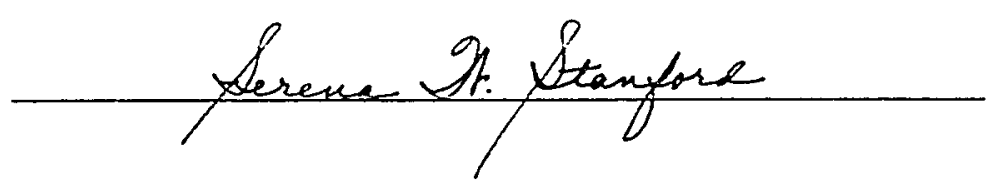




\begin{abstract}
Spring Foraging of Sanderling (Calidris alba) in Response to Aggregations of Emerita analoga Megalopae
\end{abstract}

\author{
by Veronica B. Estelle
}

Large flocks of sanderling (averaging 250-300 individuals) were observed foraging in the mid-intertidal of beaches in Monterey Bay, California during spring migration $1989 \& 1990$. As they foraged, flocks created long, narrow disturbances ("feeding plots") within a narrow intertidal band. Prey types present within this region were Emerita analoga megalopae, E. analoga juveniles, and Excirolana sp. Prey were distributed in patches dominated by Emerita megalopae. Abundance of megalopae increased significantly, whereas Emerita juveniles' and Excirolana abundance did not change during February - March. Sanderling significantly reduced megalopae but not Excirolana abundance within a prey patch. The proportion of prey consumed was calculated for feeding plots and graphed against their initial prey density. As initial density increased, variation in proportion of prey consumed decreased. At higher prey densities ( $>13$ megalopae or $>9$ Excirolana per core) within a feeding plot, sanderling consumed an average $52 \%$ of the megalopae and $22 \%$ of the Excirolana present. 


\section{ACKNOWLEDGEMENTS}

The completion of this project and my stay at MLML brings forth a myraid of reflections and emotions. Overwhelmingly my experience at MLML was positive and encouraging. The people, the sanderling, and the beach made it so. The supportive and respectful guidance of my committee kept me going at all stages of my graduate career. Special thanks and warmth to Jim Harvey for his insights, interest in my work, and friendship over the years. To Jan Hodder for being my mentor/friend and for putting binoculars in my hands to begin with. And to Mike Foster for teaching me the art of experimental design and the necessity of knowing my questions.

Also deserving of many thanks are all the people who helped me in the field. The list is long, and includes students working on associated projects, friends who helped, and folks associated with Elkhorn Slough. I would especially like to thank Petra Davidson, Rob Edwards, Kim Kiest, Susan McBride, Michelle Reed, Cassandra Roberts, and Debbie Wyatt for their incredible enthusiasm in all phases of the field work, discussions of ideas, and sharing the excitement of watching sanderling flocks feed.

Thanks also to Shelia and Sandi for all the references and stories. I hold dear memories of watching birds from the library window with Shelia. May they both get their dream library, by the shore, soon.

Financial support was provided by the Earl and Ethyl Myers Marine Biology Trust Fund, Women in Biological Sciences, and my family. Endless thanks to these organizations and people for their support.

A final expression of gratitude goes to the sanderling and the beach for teaching me what no individual or book could. The time I spent out and looking was by far the best part of my project; it is to both of these muses that I offer thanks.

I would like to dedicate this thesis to my father and mother for their love and wishes that I follow what makes me happy. I have. 


\section{TABLE OF CONTENTS}

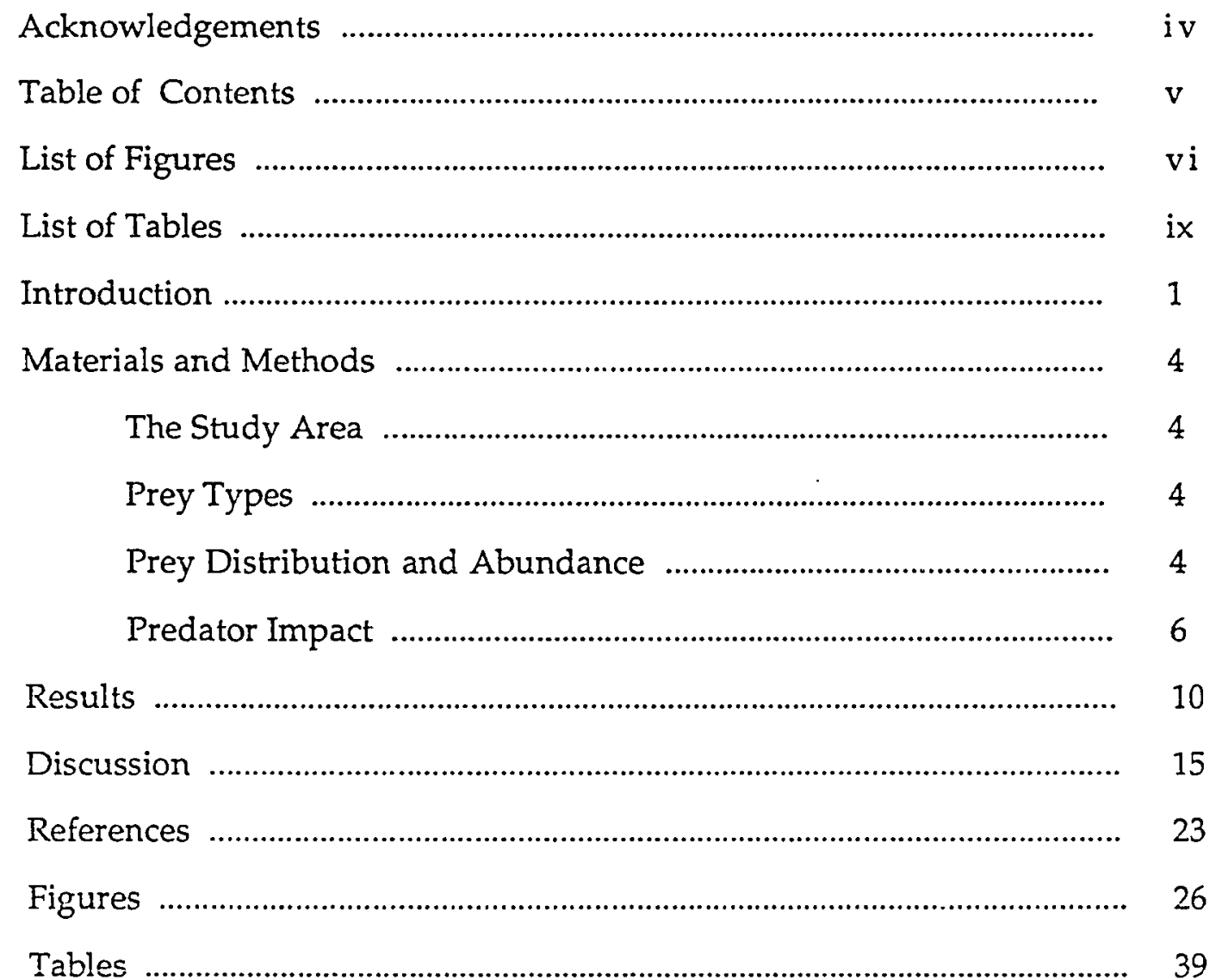




\section{LIST OF FIGURES}

Figure

Page

1. Location of study beaches (Sunset, Zmudowski, and Potrero

State Beaches) within Monterey Bay, California.

2. Longitudinal sampling of eight feeding plots in 1989.

A transect tape was placed along the long axis of a plot, and was extended from the ends of the plot for a distance equal to its length. Three cores were taken every five meters in a square meter centered on the transect tape, and their location (inside or outside) was noted.

3. A-E sampling design of six feeding plots in 1990.

A feeding area was composed of five zones, A - E. The feeding plot, zone $C$, was that location heavily foraged by a flock of sanderling, whereas zones $A, B, D$, and $E$ were nonforaged locations surrounding $C$. Zone $D$ was lower tidally than zone $C$, and zone $B$ was higher tidally than zones $\mathrm{D}$ or $\mathrm{C}$. A zone's length and width were determined by the size of plot sanderling made while foraging; $B, C$, and $D$ were the same width and length; $A$ and $E$ were three times the width, but half the length of zone $C$.

4, A-F.

Mean prey abundances $( \pm S E$ ) per $6 \times 50$ meter swath of beach $(n=6)$ are plotted against distance sampled along a beach during three, five-day intervals. $A / B, C / D$, $E / F$ all represent day 2 and day 5, respectively, of their sampling periods. Darkened lines underneath each figure, labeled with the date of observation, illustrate the location of sanderling feeding plots along the same distance of beach for a given day of observation or sampling. Figures $A / B$ and $E / F$ represent data collected from Sunset Beach, and figures C/D represent Potrero Beach. 
$5, \mathrm{~A} \& \mathrm{~B}$.

Mean abundance ( \pm SE) of Emerita analoga and

Page

Excirolana sp. inside and outside eight feeding plots in 1989. Mean abundances are reported per three cores

$\left(1875 \mathrm{~cm}^{3}\right)$. Statistical tests used were either a

Mann-Whitney (MW) or Student's t-test ( $\mathrm{St}$ ); $\mathrm{p}$ values

are as indicated. An asterik represents significant differences between inside and outside prey abundances for an individual plot.

6, A-F.

Six areas (graphs A - F) in which sanderling foraged were divided into five zones, $\mathrm{A}-\mathrm{E}$, for sampling. Zone $\mathrm{C}$ was heavily foraged (e.g. feeding plot), whereas zones $A, B, D$, and $E$ were unforaged. Number of random cores taken in each zone of a given feeding area are indicated in legends. Significant differences in mean prey abundance among zones within a feeding area were determined using Kruskal-Wallis tests ( $\mathrm{p}$ values as indicated).

7,A\&B.

Mean abundances $( \pm \mathrm{SE}$ ) of Emerita analoga megalopae, juveniles, and Excirolana sp. underneath and beside control (A) and experimental (B) exclusion boards. Mean abundances of Emerita megalopae under and beside experimental boards were compared for differences using a paired $t$-test, whereas all other under vs. beside comparisons were made using Wilcoxon Signed-Rank tests. Significant differences are indicated with an asterik, and all $p$ values are reported in results. 
8, A\&B.

Page

The proportion of Emerita analoga megalopae (A) or Excirolana sp. (B) consumed by sanderling foraging in a flock. Each point represents under and beside board pairs from the exclusion experiment. Proportion of prey consumed is the difference between abundance under a board and beside the board divided by abundance beside the board. Initial prey density is the abundance of $E$. analoga megalopae or Excirolana $\mathrm{sp}$. in the core under a board. Solid lines were inserted at 13 Emerita $/ 624.92 \mathrm{~cm}^{3}$ and 9 Excirolana $/ 624.92 \mathrm{~cm}^{3}$ to indicate the initial prey density at which variation in the proportion decreased.

9, A\&B.

Mean abundance of Emerita megalopae and Excirolana under and beside experimental boards when the initial density of prey (cores under boards) was $\leq 13$ megalopae or $\leq 9$ Excirolana $/ 625 \mathrm{~cm}^{3}(\mathrm{~A})$, and when initial density was > 13 megalopae or $>9$ Excirolana $/ 625 \mathrm{~cm}^{3}$ (B). 


\section{LIST OF TABLES}

Table

Page

1. The index of dispersion, $I=\left(s^{2} / x\right)(n-1)$, of each prey

type on the 2 nd and 5 th days of sampling during

5-day intervals on Sunset and Potrero beaches in

Monterey Bay. Day 2 and day 5 indices were compared

to a Chi Squared critical value to determine

distributional pattern of a prey type. Sample sizes and

probability level at which an index was significantly

different from a random distribution (e.g. greater than

one) are provided. An asterik indicates a random

distribution, no asterik indicates a clumped distribution.

2. Mean abundances ( $\pm \mathrm{SE}$ ) of Emerita analoga megalopae and juveniles and Excirolana during 5-day sampling intervals on Sunset and Potrero Beaches. Differences in abundance for each prey type between day 2 and day 5 were tested using either Mann-Whitney (MW) or Student's t-test (St). Sample sizes and probalility levels at which significant differences occurred are provided.

3. Results of Fligner-Policello multiple comparison tests. Comparisons of mean abundances between feeding plot (C) and surrounding zones $(A, B, D, \& E)$ within a sanderling forage area. NS indicates no significant differences, and an asterik indicates significance at $\mathrm{p}<0.05$. 


\section{Introduction}

Foraging ecology of sanderling (Calidris alba) has been studied during the nonbreeding season when the birds inhabit temperate and tropical coasts worldwide. Researchers have examined the behavioral traditions and flexibility displayed by the species. Myers (1979) and Myers et al. (1979) reported sanderling in Bodega Bay, which were winter residents, regularly established feeding territories on beaches. Sanderling maintained these territories throughout the nonbreeding season, and some returned the following year and re-established their territories. Sanderling of Bodega Bay also demonstrated flexibility in their foraging by moving between open beach and harbor mud/sand flats to forage, thereby taking advantage of a larger foraging area than if they had remained on the beach (Connors et al. 1981). Flexibility in foraging ecology of the sanderling certainly contributes to their survival throughout the world and under a variety of conditions.

During late winter and spring (northward migration) in Monterey Bay, California, sanderling rarely exhibited territorial displays, and did not switch between beach and estuarine mud/sand flats for foraging. These sanderling predictably foraged in large flocks in the mid-intertidal during the lowest spring tides. Flock sizes were variable (ranging from 50 to 2500 sanderling), but typically included 200 to 300 individuals during spring 1989 and 1990 (peak abundances were in mid to late March).

Sanderling flocks foraged within a band of intertidal approximately $3 \mathrm{~m}$ wide, and parallel to the water (estimated tidal height of +0.6 to $+1.2 \mathrm{~m}$ above mean lower low water). Obvious and discrete patches (hereafter called feeding plots) of completely pecked and churned beach were the result of their 
foraging. Feeding plots were found on low profile, fine-sand beaches, and varied in size from 5 to $190 \mathrm{~m}^{2}$, but averaged $54 \mathrm{~m}^{2}$ (length $>>$ width).

Primarily three prey species were available to flocks of sanderling in this range of mid-intertidal beach. These prey are post larvae and juveniles of the hippid crab Emerita analoga, and the isopod species Excirolana linguifrons and Excirolana chiltoni (identification by James Carlton). Post larvae (megalopae) of $E$. analoga are seasonal in their occurrence, appearing in peak abundances in southern California in fall and spring (Perry 1980). They may aggregate in a narrow, dense band within the mid-intertidal (Efford 1965); commonly, they settle within $30 \mathrm{~mm}$ of the surface (pers. obs.). Within an aggregation, Efford (1965) estimated an average 33,100 megalopae and juveniles occured within a square meter on a beach in southern California. Jennifer Dugon (UCSB, pers. comm.) estimated up to 10,000 megalopae per meter length of beach on southern California beaches.

Excirolana occur on a more regular basis than Emerita megalopae. For example, E. chiltoni release young from brood pouches during each spring tide series (Klapow 1971), typically, higher in the intertidal than Emerita megalopae aggregate. Young E. chiltoni increase their swimming behavior on waning spring tides, and move lower in the intertidal (Enright 1972), thus mixing with Emerita megalopae. Myers (1979) described Excirolana linguifrons density as variable, ranging from less than 300 to more than 1000 individuals $/ \mathrm{m}^{2}$, and averaging 580 E. linguifrons $/ \mathrm{m}^{2}$ in territories defended by individual sanderling.

Sanderling foraging on Emerita megalopae aggregations has been mentioned only briefly in the literature; no quantitative examination of this relationship has been conducted, and no reports of large flocks of foraging sanderling have been published (Efford 1965, Pitelka et al. 1978, Myers 1979). 
Presence of an abundant prey source coinciding with northward migration of shorebirds has been documented in Delaware Bay where a million shorebirds feast on tons of horseshoe crab (Limulus polyphemus) eggs each year (Myers 1987, Biderman 1983, Joyce 1986). In Delaware Bay, sanderling forage alone and may defend a cache of eggs. While feeding on these eggs, sanderling can double their weight in two weeks (Joyce 1986). Aggregations of megalopae in Monterey Bay may, like horseshoe crab eggs, provide an important food source for sanderling using Monterey Bay during their spring migration.

The objectives of this research were to 1) establish whether sanderling fed in areas of high prey concentrations, 2) determine whether sanderling consumed proportionally more Emerita megalopae than juveniles or Excirolana, and 3) determine the amount of prey consumed per core within a feeding plot.

The following specific hypotheses were tested: 1) prey types are distributed in clumps throughout the study area, 2) mean abundance of Emerita analoga megalopae increases during February through March, whereas Emerita juvenile and Excirolana abundances do not change, 3) sanderling feeding plots are associated with areas of peak prey abundance, 4) prey abundance is greater inside a feeding plot than outside, 5) sanderling reduce the abundance of all prey types within a feeding plot, and 6) there is a threshold in prey density beyond which sanderling significantly reduce prey density and below which they do not significantly reduce it. 


\section{Materials and Methods}

Study area. From late January to mid-April of 1989 and 1990, sanderling feeding was investigated in Monterey Bay, California on Sunset, Potrero, and Zmudowski State Beaches (Fig. 1). At this time of year, beaches have low profiles, and are composed of medium to fine sand (McBride and Wyatt, unpublished data). Core samples (101 mm diameter, $78 \mathrm{~mm}$ deep; 625 $\mathrm{cm}^{3}$ ) were collected within an estimated tidal height of +0.6 to $+1.2 \mathrm{~m}$ above mean lower low water on these beaches.

Prey type. Prey items were initially identified in the laboratory as megalopae and juvenile Emerita analoga (Decapoda), and as Excirolana chiltoni and Excirolana linguifrons (Isopoda). Because the two species of Excirolana could not be distinguished in the field, they were grouped in this study. Megalopae of $E$. analoga were distinguished from juveniles by their ventral setose pleopods, transparent bodies, and two orange chromatophores on the carapace posterior to the eyes. Juvenile $E$. analoga were a blueish tint (younger juveniles) to tan, and later grey color (older juveniles) with no ventral setose pleopods or chromatophores.

\section{Prey distribution and abundance}

Sections of Potrero and Sunset State beaches upon which sanderling flocks foraged were observed and sampled in 1990 to 1) determine prey distribution and abundance in these areas, and 2) assess whether sanderling feeding plots were located in areas of greatest prey abundance. Three, five-day 
sampling intervals were conducted during the lowest tides of February and March.

For each interval the following protocol was used: On day 1, Potrero and Sunset beaches were monitored for flock foraging so that a study site for the sampling interval could be chosen. Selection of a site was obvious because sanderling flocks generally created feeding plots on only one of these beaches during a low tide series. Also on day 1, all feeding plots within the selected study site were marked so that tidal height and location of foraging could be relocated on day 2 .

On days 2 and 5, prey distribution and abundance within the study site were determined. A 50-m transect tape (parallel to the water) was aligned with feeding plot markers of the previous day(s). Six randomly placed cores were collected within a $6 \mathrm{~m}$ wide strip centered along the length of the transect tape; 3 cores were taken intertidally higher than the tape and 3 cores lower. Core contents were sieved through a $1-\mathrm{mm}$ mesh and enumerated by genus and age class (in the case of Emerita). This protocol was repeated for distances of 600 (February 20 \& 23, Sunset Beach), 500 (March $6 \&$ 9, Potrero Beach), and 700 (March $22 \& 25$, Sunset Beach) meters. Distances sampled were determined by duration of mid-intertidal exposure; cores were not collected from areas washed by an incoming tide.

On days 3 and 4 , the study site was observed for presence of sanderling feeding plots. Length and location of all plots were recorded, and again, markers were placed at all plots. Location of markers determined placement of the transect tape and sampling on day 5 . 
Analysis: An index of dispersion, I, (Andrew and Mapstone 1987) and mean abundance of each prey type were calculated for days 2 and 5 of all sampling intervals. Additionally, the grand mean for the abundance of each prey type was calculated for the two sampling intervals on Sunset Beach.

Significant changes in prey distribution between days 2 and 5 were tested by comparing I to a Chi-Squared critical value. Changes in mean abundance between days 2 and 5, and over a month (Sunset Beach), for each prey type, were tested using a Student's t-test, if variances were equal, or a Mann-Whitney test, if variances were unequal (F-test).

\section{Predator Impact}

Prey abundance inside and outside feeding plots on Potrero, Sunset, and Zmudowski State Beaches was assessed using two methods. In 1989, the area sampled "outside" was that extending from either end of a plot and within its same tidal height. In 1990, "outside" consisted of regions higher and lower in the intertidal than the plot, plus those areas on either end of the plot. In both methods, the dimensions of the area sampled "outside" were based on the length and width of the plot.

In 1989, the inside of a feeding plot was sampled along a transect tape centered on a plot's long axis (parallel to the waterline). Outside a plot was also sampled along a transect tape stretching from either end of a plot to a distance equal to the plot's length (Fig. 2). At 5-m intervals along the transect tapes, 3 cores were haphazardly collected within a square meter centered on the tape. Cores were collected in this manner inside and outside 8 feeding 
plots. Abundance of E. analoga (megalopae and juveniles were not distinguished during 1989) and Excirolana sp. were recorded.

Analysis: Equality of variances among inside plot samples and among outside plot samples for plots 1-8 was tested using Leven's test (Snedecor and Cochran 1967). Samples taken inside and outside plots 1-8 had unequal variances $(E$. analoga, inside $\mathrm{p}=0.0083$, outside $\mathrm{p}=0.0003$; Excirolana, inside $p=0.0001$, outside $p=0.0001$ ). Differences in prey abundance between inside and outside plots were therefore analyzed per plot. An individual sample represents the pooled abundance of a given prey type from the 3 cores collected at $5-\mathrm{m}$ intervals. Abundance of each prey type was summed for 3 cores because individual cores were not randomly positioned within the $5-\mathrm{m}$ intervals, and were not independent measures of abundance.

Equality of variances inside and outside each plot was tested using an F-test. Sample variances of $E$. analoga inside and outside plots 3, 6, and 7 were not equal ( $\mathrm{p}<0.05, \mathrm{p}<0.02, \mathrm{p}<0.001$, respectively). Consequently, differences in mean abundance between inside and outside these plots were tested using Mann-Whitney tests. All other inside vs. outside comparisons were analyzed using Student's t-test (normality of data was determined using D'Agostino's test).

From late February to mid-April, 1990, differences in prey abundance inside and outside 6 feeding plots were determined with a second method of sampling. In contrast to the method used in 1989, "outside" a feeding plot was defined as that area encompassing the plot. Feeding plots and their immediate surroundings were called feeding areas in this sampling method. Each feeding area was divided into 5 zones for sampling (Fig. 3). The feeding 
plot, zone $C$, was in the center of the feeding area. Zones $A$ and $E$ lay on either end of the feeding plot, and were one half the length of the feeding plot and three times its width. Zones $B$ and $D$ lay intertidally higher and lower than the feeding plot, respectively. Zones $B$ and $D$ were the same length and width of the feeding plot. Cores were placed randomly within each zone.

Analysis: Equality of variances among zones $\mathrm{A}$ through $\mathrm{E}$ within a feeding area (for each prey type) was tested using Leven's test. Because a majority of the Leven's tests indicated unequal variances $(p<0.0001-0.04)$, a difference in prey abundance among these zones (for individual feeding areas) was determined using a Kruskal-Wallis test.

Given a significant result in a Kruskal-Wallis test, planned comparisons (A vs. $C, B$ vs. $C, D$ vs. $C, E$ vs. $C$, and $(A, B, D, E)$ vs. $C$ ) of prey abundance between zones were made using the Fligner-Policello Planned Multiple Comparison test (Day and Quinn 1989). These comparisons were chosen to examine the relationship between an unforaged zone(s) and a foraged zone; the factor of tidal height is not controlled for in this testing.

Finally, an exclusion experiment was conducted with flocks of foraging sanderling to determine whether they reduced the abundance of Emerita megalopae and Excirolana sp. equally within a feeding plot. Up to 15 plywood boards $\left(232 \mathrm{~cm}^{2}\right)$ were haphazardly placed along the edges and ends of 6 feeding plots as they were being formed. This was done by slowly moving toward a feeding plot, temporarily interrupting the foraging sanderling, placing boards around a plot, and then retreating. After all boards were in place, sanderling returned to the plot and resumed foraging. If sanderling fed completely around a board, 1 core was collected from underneath 
(representing before foraging) and 1 core from beside (representing after foraging) the board. If sanderling did not feed around a board at all, cores taken under $(n=1)$ and beside $(n=1)$ the board were used as a control for a possible board effect.

Analysis: Sample differences, $\mathrm{d}_{i}$, in abundance of megalopae and juvenile E. analoga and Excirolana sp. under and beside boards (control and experimental) were tested for normality using D'Agostino's test (Zar 1984). Only sample $d_{i}$ 's of Emerita megalopae (experimental) were normally distributed ( $p<0.05$ ). Differences in Emerita megalopae abundance under and beside boards were tested using a paired t-test, whereas Emerita juvenile and Excirolana sp. differences, and all controls, were tested using Wilcoxon Signed-Rank tests.

In order to examine possible trends between initial prey density in a feeding plot and the proportion of prey a sanderling flock consumed in that plot, the "proportion of prey eaten" was calculated for Emerita megalopae and Excirolana sp.. This proportion is defined as the difference between abundance underneath and beside an exclusion board divided by abundance underneath the board. In 14 of 36 cases, abundance of Excirolana was zero in the core taken under a board; these samples were not included in the calculation of "proportion of prey eaten." 


\section{Results}

\section{Prey distribution and abundance}

Prey were distributed in a clumped manner during February and March, 1990 on Potrero and Sunset State Beaches (Table 1). This distribution generally did not change between day 2 and day 5 of sampling: Emerita analoga juveniles were distributed in a random pattern only on March 9th.

Mean abundances of Emerita megalopae and juveniles, and Excirolana sp. were the same on day 2 and day 5 of sampling in 5 out of 9 cases (Table 2). Prey were more abundant on day 5 of sampling than day 2 in 3 instances (Emerita megalopae twice and Emerita juveniles once), and were less abundant on day 5 than day 2 in 1 case (Excirolana sp.). By the end of March, more Emerita megalopae and less Excirolana sp. were present on Sunset Beach than were measured there at the end of February (Mann-Whitney test, p $<0.0005$; Fig. 4 A, B, E, and F); abundance of Emerita juveniles did not significantly change over the month (Mann-Whitney test, $p>0.25$ ).

No clear relationship between the abundance of prey and locations of sanderling feeding plots was observed during the 5-day sampling intervals (Fig. 4, A-F). For example, on February 20, Sunset Beach (Fig. 4 A), location of feeding plots coincided with two peaks in Excirolana abundance and two peaks in Emerita juvenile abundance, but on March 6, Potrero Beach (Fig. 4 C), there were no feeding plots in the area of peak Excirolana abundance. Greatest abundance of Emerita megalopae coincided with locations of feeding plots during March 7-9 (no feeding plots formed on March 6), but few plots 
were formed during March 22-25 when megalopae abundance was slightly less than March 6-9 (Fig. 4, D, E, and F).

Although associations between locations of feeding plots and peaks in prey abundance did not appear evident, comparison of sampling intervals suggested sanderling formed more feeding plots when Emerita megalopae and Excirolana sp. abundance was greatest. For example, the greatest number of feeding plots, and percentage of study area foraged, occurred when Emerita megalopae and Excirolana sp. abundance was highest and Emerita juvenile abundance lowest (Fig. 4, C and D). Additionally, more feeding plots were made on Sunset Beach at the end of March when megalopae abundance was greater than at the end of February (Fig. 4, A, B, E, and F).

The inability to demonstrate an exact association between prey abundances and locations of sanderling feeding plots was due partially to high variability associated with mean prey abundances (Fig. 4, A-F). Imprecise estimates of prey abundance probably arose as a result of a patchy prey distribution, and a limited number of cores $(n=6)$ taken in each $6 \times 50 \mathrm{~m}$ section.

\section{Predator Impact}

In 1989, when feeding plots were sampled inside and out along a line parallel to shore, mean abundance of $E$. analoga was greater within a plot (e.g. foraged by sanderling) than outside in 5 out of 8 plots sampled (Fig. 5A). In the remaining 3 plots, E. analoga abundances inside and outside a feeding plot did not differ significantly (Fig. 5A). Mean abundances of Excirolana were not 
different inside vs. outside a feeding plot in seven plots sampled (no data for plot 6; Fig. 5B).

In 1990, mean abundances of Emerita megalopae and Excirolana sp. differed significantly among zones A-E in all feeding areas (Fig. 6, A-F). Abundances of Emerita juveniles among zones A-E were different only in feeding areas 2, 3, and 4 (Fig. 6, A - F).

Mean abundances of Emerita megalopae were greater within the foraged zone $(C)$ than within surrounding, unforaged zones $(A, B, D$, or $E$, and all pooled) in 19 of 30 comparisons tested (Table 3). Mean abundance of Emerita juveniles was greater within the foraged zone (C) than within surrounding, unforaged zones in 8 of 15 comparisons tested (A, B, D, or E, and all pooled; Table 3). Juvenile abundances in foraged and nonforaged zones did not differ significantly in plot 2 for the comparisons that were tested ( $p>0.05$ ); the significant difference among zones, as indicated by the KruskalWallis test, must lie in some other untested comparison(s). In contrast to megalopae and juveniles, mean abundance of Excirolana sp. was greater in zones $A, B$, and $E$ than in zone $C$, and lesser in zone $D$ than $C$ in 16 of 30 comparisons (Table 3).

Use of control boards during the exclusion experiment indicated in the absence of foraging sanderling, mean abundance of Emerita megalopae and Excirolana sp. was not influenced by the presence of boards (megalopae, $\mathrm{n}=44, \mathrm{p}>0.20 ;$ Excirolana $, \mathrm{n}=38, \mathrm{p}>0.50 ;$ Fig. 7A). In the case of Emerita juveniles, however, more were found under control boards than beside them $(n=14, p<0.025 ;$ Fig. 7A) 
Within feeding plots, mean abundance of Emcrita megalopae decreased significantly by an average $36 \%$ after sanderling foraged $(n=36$, $\mathrm{p}=0.0004 ;$ Fig. 7B). Abundance of Excirolana also decreased, by an average $9 \%$, but the decrease was not significant $(n=21, p>0.20$; Fig. $7 B$ ). Mean abundance of Emerita juveniles was greater under experimental boards than beside them (Wilcoxon Signed-Rank test, $n=13, p<0.025$ ). Because the boards may have affected juvenile location, it was not clear how sanderling flocks impacted juveniles.

An average $13.8(\mathrm{SE}=1.45)$ Emerita megalopae $/ 625 \mathrm{~cm}^{3}$ were found in cores collected underneath boards within a feeding plot. This is an estimate of prey density at which sanderling began feeding. Sanderling stopped foraging in a feeding plot when there was an average $8.7(\mathrm{SE}=0.92)$ megalopae $/ 625 \mathrm{~cm}^{3}$ (calculated from cores taken beside boards within a feeding plot). Sanderling did not make feeding plots when the average density of megalopae was $4.7 / 625 \mathrm{~cm}^{3}(\mathrm{SE}=0.63$ ) (calculated from cores taken underneath control boards).

When the "proportion of prey eaten" was graphed against initial prey density within a feeding plot for Emerita megalopae (Fig. 8A) and for Excirolana (Fig. 8B), variation decreased at a density $>13$ megalopae $/ 625 \mathrm{~cm}^{3}$ and $>9$ Excirolana $/ 625 \mathrm{~cm}^{3}$; at densities greater than these, no negative proportions occurred. A negative proportion resulted when more prey were found beside an experimental board than underneath it. Presentation of these proportions illustrate the higher variability in prey abundance within feeding plots when initial prey densities were low (e.g. $\leq 13$ megalopae/ 625 $\mathrm{cm}^{3}$ and $\leq 9$ Excirolana $/ 625 \mathrm{~cm}^{3}$ ). 
When exclusion data were re-examined for differences in prey abundance under and beside boards, sanderling did not decrease the abundance of megalopae when its initial density was $\leq 13$ individuals/ 625 $\mathrm{cm}^{3}$ (Paired t-test; $\mathrm{n}=21, \mathrm{p}=0.9261$, Fig. 9A). However, at an initial density of $>13$ megalopae $/ 625 \mathrm{~cm}^{3}$, sanderling decreased its abundance by $52 \%$ (Paired t-test; $n=15, p=0.001$, Fig. 9B).

Regardless of the initial density of Excirolana, sanderling did not consume significant amounts of them within a feeding plot (Paired t-test; $\mathrm{n}=33, \mathrm{p}=0.8835$, Fig. 9A and $\mathrm{n}=3, \mathrm{p}=0.0927$, Fig. 9B). At a density $>9$ Excirolana $/ 625 \mathrm{~cm}^{3}$, sanderling consumed an average $22 \%$ of the prey, but this was not a statistically significant reduction in abundance. 


\section{Discussion}

Other researchers have reported clumped distributions of Emerita analoga and Excirolana sp., although they did not clearly distinguish age classes of Emerita (Barnes and Wenner 1968, Myers 1979, and Perry 1980). Efford (1965), however, specifically discussed the aggregated distribution of megalopae and juveniles in the mid to upper intertidal. He reported patches of Emerita megalopae and juveniles were visually obvious on Scripps Beach, California, that sanderling were the only avian predators feeding on these aggregations (they "gather round and feed voraciously"), and that aggregations of megalopae and juveniles did not move laterally from day to day. On Potrero and Sunset Beaches, there were no visual cues associated with Emerita megalopae and juvenile patches, and sanderling were the only bird feeding on these aggregations at low tide. In agreement with Efford, there is some quantitative evidence in this study that aggregations of megalopae and juveniles did not move laterally (Fig. 4, E and F), but it is limited because of difficulties in precisely measuring prey abundance. Occassionally sanderling were observed feeding in the same patch location from day to day, thereby, providing an indication that at least some patches of Emerita megalopae and juveniles remained in the same location during a few-day period.

The increase in overall mean abundance of Emerita megalopae on Sunset beach during late February to late March was indicative of a settlement event. The timing of this settlement is earlier than recorded by Myers (1979) in Bodega Bay (April). As suggested by Johnson (1939), 
settlement of megalopae on beaches is correlated with water temperature and circulation patterns, both of which vary with location. Because most sanderling using the Pacific flyway migrate northward during March - May (Myers et al. 1990), the later settlement of megalopae in Bodega Bay would be advantageous to birds stopping and feeding in both Monterey and Bodega Bays.

Metamorphosis of megalopae into juveniles requires approximately one month (J. Dugon, pers. comm.). The observation that juvenile abundance remained low and did not change during this study is consistent with the molting schedule of Emerita analoga. Fluctuation in Excirolana sp. abundance has been noted by Enright (1972), and is most likely related to its bi-monthly reproductive pattern.

To precisely estimate abundance of a population, its spatial scale of aggregation must be known (Andrew and Mapstone 1987). Although distributions of Emerita (megalopae and juveniles) and Excirolana sp. typically remained aggregated during this study, the scale on which they aggregated varied markedly. Myers (1979) also found this true when he reported large decreases in Emerita and Excirolana abundances (1000 to 0 individuals $/ \mathrm{m}^{2}$ ) over relatively short distances ( 25 and $50 \mathrm{~m}$, respectively), and sustained abundances (e.g. 450 Emerita $/ \mathrm{m}^{2}$ and 1000 Excirolana $/ \mathrm{m}^{2}$ ) over longer distances ( $200 \mathrm{~m}$ and $600 \mathrm{~m}$, respectively). Because of this variation, precise measurement of prey abundance, particularly over long distances of beach, was difficult with the limited number of cores taken.

Precision in abundance estimates can be increased by taking more samples or by increasing size of the sampling unit (thereby decreasing 
sample variation; Andrew and Mapstone 1987). Obtaining more samples during the 5-day sampling intervals was not feasible given the amount of time allowed for sampling (dictated by the tides) and behavior of the birds. Andrew and Mapstone (1987) also recommended using a sampling unit larger than the size of the average prey aggregation. Because the size of megalopae and Excirolana aggregations was so variable, use of a very large core was not feasible. However, a larger core would have reduced variation in these samples.

Because of natural variation and the problem with sampling unit size, abundance measurements during the 5-day sampling intervals had large standard errors. In many cases, this variance meant that average abundances of the different prey types could not be clearly distinguished; the original goal of defining peak abundances was not met. Without a more precise estimation of prey abundance within the $6 \times 50 \mathrm{~m}$ swaths, determining whether feeding plots were located on concentrations of prey was not possible. Given the range of variation encountered in this sampling scheme, 150 - 600 cores were necessary within a $6 \times 50 \mathrm{~m}$ swath of beach to estimate megalopae abundance with a precision of 0.10 (Andrew and Mapstone 1987; $\left.\mathrm{n}=[\mathrm{s} /(\mathrm{px})]^{2}\right)$. Concentrating the same or greater sampling effort in a smaller swath of beach while using a larger sampling unit would have improved this study.

Sampling individual plots inside and out demonstrated that feeding plots were associated with areas of prey aggregation. The plots where sanderling fed generally had a greater abundance of megalopae even after feeding occurred than areas just outside them. For Excirolana, the 
abundance inside a plot was less than or equal to the abundance outside. Sanderling flocks, therefore, fed on prey patches dominated by Emerita megalopae.

Because all of the plots sampled did not show the abundance trends noted above, it is important to note each feeding plot (as well as the entire beach) has an unknown, recent "history" which undoubtedly effects the foraging of a flock of sanderling. Factors which constitute a patch's history include initial and relative prey abundances before sanderling feed, recruitment and emmigration of prey in a patch, and the impact of other predators (i.e. fish, MacGinitie 1938 and Perry 1980) on prey abundances.

An example in which knowing the history of a patch would be useful is in explaining why almost half the multiple comparisons between foraged and unforaged zones of a feeding area (1990) were not significant for any of the prey types. In this situation there are at least two explanations related to the history of a patch which may explain the similarities in abundance between inside and outside: 1) sanderling did not feed in a patch or 2) sanderling found a patch dominated by megalopae, and reduced its abundance to surrounding levels, but did not forage on the other prey types. The latter explanation is consistent with results of the individually sampled plots of 1989 and with the exclusion experiment.

The use of exclusion devices has often been employed to determine the impact of predators on their prey (Quammen 1981, Goss-Custard 1977, Schneider 1978), and with varying degrees of success. Common problems with this technique have been in the pseudoreplication of treatments and 
controls (Quammen 1981), mobile prey (Goss-Custard 1977), and the lack of controls for exclusion devices (Schneider 1978).

In this current study, placement of exclusion boards did not affect birds' feeding as evidenced by their immediate return to foraging after the researcher was an adequate distance away. Also, only boards which were completely fed around were used as experimental boards. In this way, it was assured that the presence of boards did not disturb birds' feeding. Because all boards were placed in dry sand for less than forty minutes, no changes in the environs were caused by the boards as is sometimes a problem in intertidal exclusion experiments (Quammen 1981). Boards could have potentially provided shelter for prey, but control results indicated this was a possibility for Emerita juveniles only. Observationally, it did appear that juveniles were more mobile than either megalopae or Excirolana in dry sand.

Within feeding plots, sanderling reduced the abundance of megalopae by an average $36 \%$ and Excirolana by an average 9\%. Whether this indicates sanderling were selectively feeding on megalopae within patches is unclear; sanderling may have significantly reduced megalopae but not Excirolana within a patch simply because megalopae were more abundant in these areas. When the beach was observed as a whole, however, sanderling foraged voraciously only in the mid-intertidal where megalopae were most abundant; they did not display the flock foraging behavior in the higher intertidal where Excirolana may approach the abundance levels of megalopae. On this larger scale, sanderling did display a choice of where to forage, and they foraged in the area (mid-intertidal) of greatest megalopae abundance. 
According to optimal foraging theory, a predator should consume prey with the greatest energy value if it is to maximize its net rate of energy intake (MacArthur and Pianka 1966, Pyke 1977, Krebs 1984); this is hypothesized to be true when all factors other than energy content are equal. Connors et al. (1981) mention that Emerita (age classes not distinguished) may contribute 30 times the amount of energy per $\mathrm{m}^{2}$ than contributed by Excirolana. Without further experiments (e.g. prey preference tests in a lab or more field exclusion experiments when abundance of prey is controlled), it is not possible to say whether sanderling foraged "optimally" in the current situation. Myers (1980) postulated that sanderling foraging was not optimal, but that they met their energy needs as required. At the time, he was studying Bodega Bay winter residents which were neither preparing for migration nor on migration, and which were not foraging as flocks.

The question of optimal foraging with migrating sanderling flocks is worthy of further investigation, particularly in the area of patch theory (Charnov 1976). The primary question of this theory is how long to feed in a patch. Considerations of patch quality (energy content of available prey and abundance of the resource) and distance between patches are thought to be important in the predator's decision process; thresholds of prey density may act as a signal to a predator as to when to give up and move on to the next patch. In this study, average densities were identified at which sanderling began feeding in a patch ( 13.8 megalopae $/ 625 \mathrm{~cm}^{3}$ ), stopped feeding in a patch ( 8.7 megalopae $/ 625 \mathrm{~cm}^{3}$ ), and did not feed in a patch $(4.7$ megalopae $/ 625 \mathrm{~cm}^{3}$ ). These values are averages resulting from patches of 
varying quality and "history," and need to be verified in other situations before they can be use in a patch model.

The possibility that initial density of prey in a patch could influence the amount of prey sanderling flocks consumed was also addressed in this study. When the initial density of megalopae in a patch was high ( $>13$ individuals $/ 625 \mathrm{~cm}^{3}$ ), sanderling consumed $52 \%$ of the megalopae in a patch, but when the density was lower ( $\leq 13$ individuals $/ 625 \mathrm{~cm}^{3}$ ), sanderling did not reduce the abundance of megalopae. Why sanderling reduced megalopae abundance when the initial density of it was high as compared to when it was low may be related to an increased foraging efficiency at higher prey densities or simply to the amount of time that the flocks spend feeding at different densities. If sanderling flocks spent a longer time feeding in an area of high megalopae abundance than in an areas of low abundance, they would reduce the amount of megalopae to different degrees.

A primary short-coming in using classical foraging theory to further investigate this foraging system exists in its use of energy intake as the primary variable of interest. The metabolic or assimilation efficiency a predator exhibits when consuming a particular prey is more important than absolute energy content of prey when estimating fitness (Castro et al. 1989). It is the ability to convert energy into lipid reserves which is crucial to migrating shorebirds. Castro et al. (1989) clearly demonstrated this point by examining the caloric content of horseshoe crab (Limulus polyphemus) eggs and the metabolic efficiency displayed by sanderling while feeding on them. Although the eggs were calorically valuable, sanderling displayed the lowest 
metabolic efficiency of any vertebrate while feeding on them. Sanderling most likely compensated for their poor efficiency with regard to this abundant and available prey source by consuming as many as possible; they doubled their weight in a two to three week period (Myers 1989, Castro et al. 1989). In this example, simply using the energy content of prey in a foraging model would have resulted in erroneous predictions.

At a time when coastal development proceeds and fewer areas remain as "oases" for migrating shorebirds, further research in the area of foraging, habitat requirements, and the behavioral plasticity of these birds is necessary. It has been estimated that along the Atlantic flyway during autumnal migration, 10 out of 12 species of shorebirds have shown a significant decline in population numbers over the last decade; sanderling led the way with an estimated $80 \%$ decline during this time period (Myers 1989). Although precise estimates of shorebird abundance are difficult to obtain, the trend of decline appears certain and has been linked to widespread use of pesticides in South America and coastal wetland destruction throughout the Americas (Myers 1989). It is hoped that further research will assist in the management and conservation of coastai and wetland habitats and communities. 


\section{References}

Andrew, N. L. and B. D. Maptsone. 1987. Sampling and the description of spatial pattern in marine ecology. Oceanography and Marine Biology an Annual Review. 25:39-90.

Barnes, N. B., and A. M. Wenner. 1968. Seasonal variation in the sand crab Emerita analoga (Decapoda, Hippidae) in the Santa Barbara area of California. Limnology and Oceanography 13:465-475.

Biderman, J. O. 1983. Food for flight. Audubon 85(3):113-119.

Brown, A. C. and A. McLachlan. 1990. The physical environment. Pages 5 - 39 in Ecology of Sandy Shores. Elsevier Science Publishers, Amsterdam.

Castro, G., J. P. Myers, A. R. Place. 1989. Assimilation efficiency of sanderlings (Calidris alba) on horseshoe crab (Limulus polyphemus) eggs. Physiological Zoology 62(3):716-731.

Charnov, E. L. 1976. Optimal foraging, the marginal value theorem. Theoretical Population Biology 9:129-136.

Connors, P. G., J. P. Myers, S. W. Connors, and F. A. Pitelka. 1981. Interhabitat movements by sanderlings in relation to foraging profitability and the tidal cycle. The Auk 98:49-64.

Day, R. W. and G. P. Quinn. 1989. Comparisons of treatments after an analysis of variance in ecology. Ecological Monographs 59(4):433463.

Efford, I. E. 1965. Aggregation in the sand crab Emerita analoga (Stimpson). Journal of Animal Ecology 34:63-75.

Enright, J. T. 1972. A virtuoso isopod: circa-lunar rhythms and their tidal fine structure. Journal of Comparative Physiology 77:141-162.

Goss-Custard, J. D. 1977. The ecology of the Wash. III. Density-related behavior and the possible effects of the loss of the feeding grounds on wading birds (Charadrii). The Journal of Applied Ecology 14:721-739. 
Johnson, M. W. 1939. The correlation of water movements and dispersal of pelagic larval stages of certain littoral animals, especially the sand crab, Emerita. Journal of Marine Research 2(3):236-245.

Joyce, C. 1986. Food for flight in Delaware Bay. New Scientist 10(1):34-36.

Klapow, L. A. 1971. The ecology and behavior of a sand-beach isopod, Excirolana chiltoni: distribution, abundance, and temporal patterns in molting, reproduction, and swimming activity. PhD. thesis, University of California, San Diego.

Krebs, J. R. 1984. Perspectives in optimal foraging. Pages 165-221 in A. H. Brush and G. A. Clark, Jr., editors. Perspectives in Ornithology. Cambridge University Press, Cambridge.

MacArthur, R. H. and E. R. Pianka. 1966. On optimal use of a patchy environment. American Naturalist 100:603-609.

MacGinitie, G. E. 1938. Movements and mating habits of the sand crab, Emerita analoga. The American Midland Naturalist 19(2):471-481.

Myers, J. P. 1980. Sanderlings (Calidris alba) at Bodega Bay: facts, inferences, and shameless speculations. Wader Study Group 30:26-32.

1979. Ecological control of spacing behavior in non-breeding shorebirds. PhD. thesis, University of California, Berkeley. 1989. Sanderling. Pages $650-666$ in W. J. Chandler, editor. Audubon Wildlife Report 1988/1989. Academic Press, Inc., 1988.

P. G. Connors, and F. A. Pitelka. 1979. Territory size in wintering sanderlings: the effects of prey abundance and intruder density. The Auk 96:551-561.

R. I. G. Morrison, P. Z. Antas, B. A. Harrington, T. E. Lovejoy, M. Sallaberry, S. E. Senner, A. Tarak. 1987. Conservation strategy for migratory species. American Scientist 75:19-26.

M. Sallaberry, E. Ortiz, G. Castro, L. M. Gordon, J. L. Maron, C. T. Schick, E. Tabilo, P. Antas, and T. Below. 1990. Migration routes of New World sanderling (Calidris alba). The Auk 107:172-180. 
Perry, D. M. 1980. Factors influencing aggregation patterns in the sand crab Emerita analoga (Crustacea: Hippidae). Oecologia 45:379-384.

Pitelka, F. A., J. P. Myers, and P. G. Connors. 1978. Spatial and resource-use patterns in wintering shorebirds: the sanderling in central coastal California. Pages 1041- 1044 in F. A. Pitelka, editor. Shorebirds in Marine Environments. Studies in Avian Biology, number 2. Cooper Ornithological Society, 1979.

Pyke, G. H. 1977. Optimal foraging theory: a critical review. Annual Review of Ecology and Systematics 15:523-575.

Quammen, M. L. 1981. Use of exclosures in studies of predation by shorebirds on intertidal mudflats. The Auk 98:812-817.

Schneider, D. 1978. Equalization of prey numbers by migratory shorebirds. Nature 271:353-354.

Snedecor, G. W. and W. G. Cochran. 1967. Statistical Methods. The Iowa State University Press, Ames, Iowa.

Zar, J. H. 1984. Biostatistical Analysis. Prentice-Hall, Inc., New Jersey. 


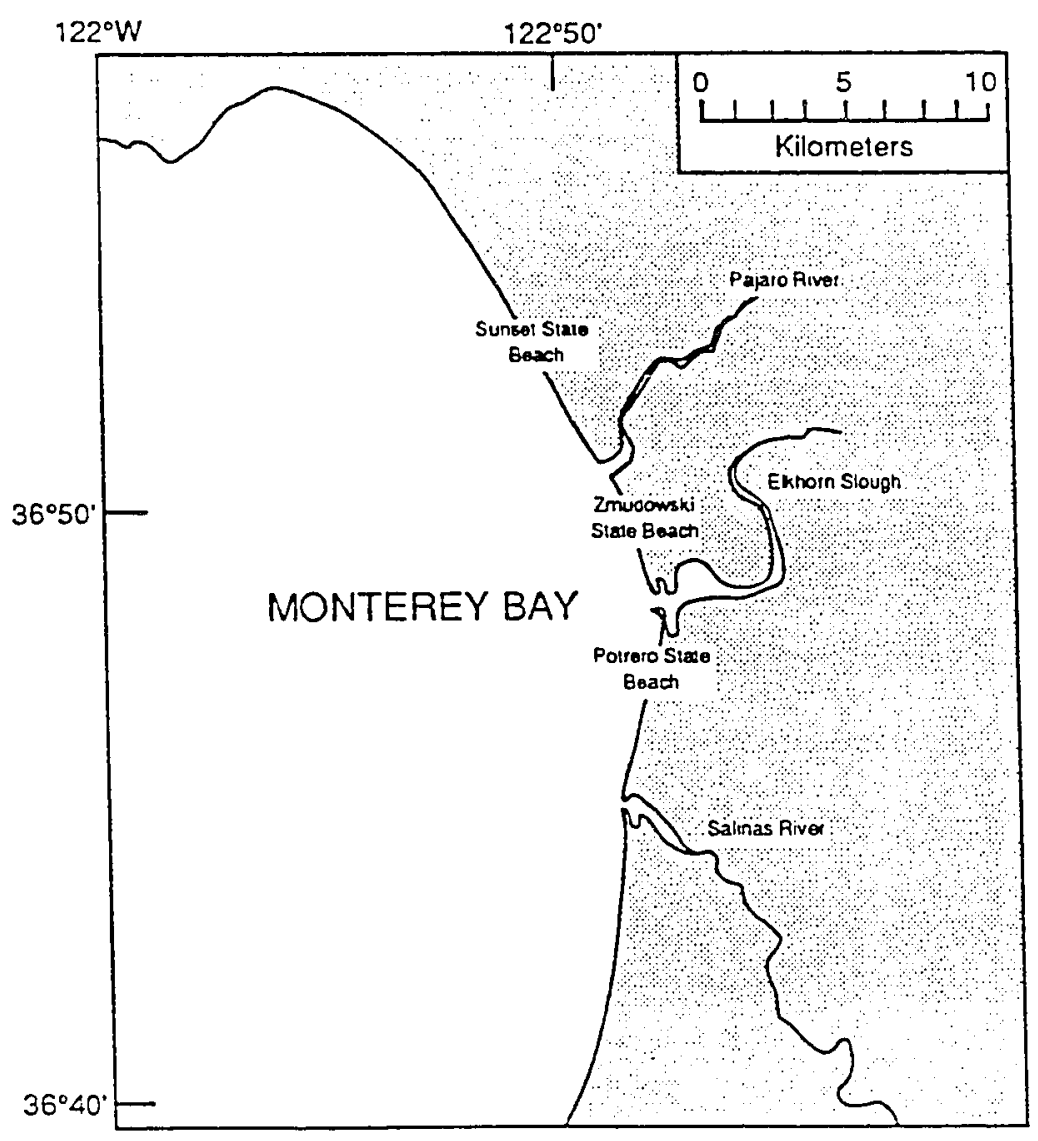

Figure 1. Location of study beaches (Sunset, Zmudowski, and Potrero State Beaches) within Monterey Bay, California. 


\section{Dunes}

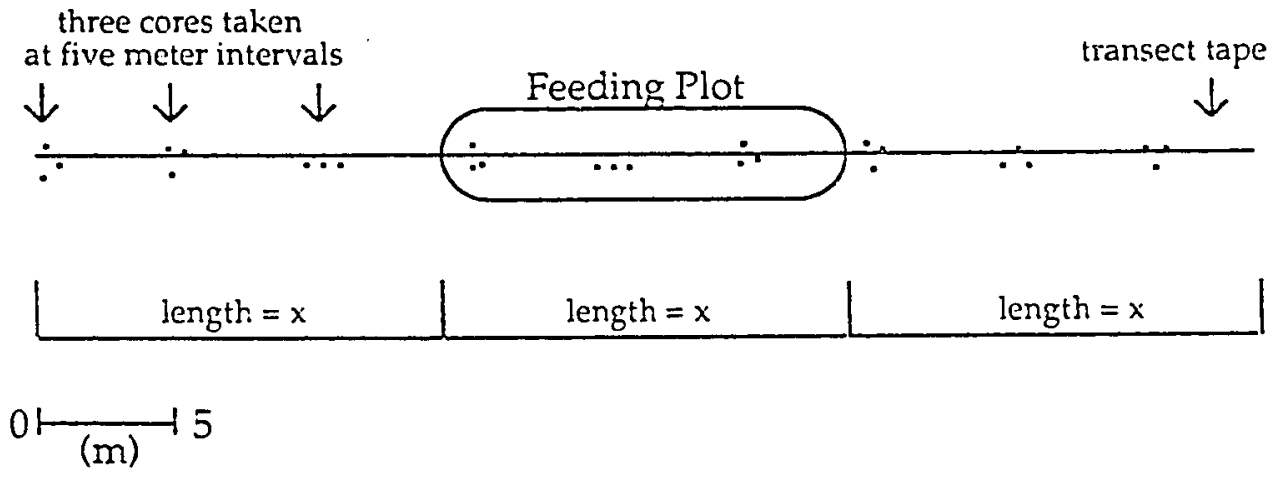

Water

Figure 2. Longitudinal sampling of eight feeding plots in 1989. A transect tape was placed along the long axis of a plot, and was extended from the ends of the plot for a distance equal to its length. Three cores were taken every five meters within a square meter centered on the transect tape, and their location (inside or outside) was noted. 


\section{Feeding Area}

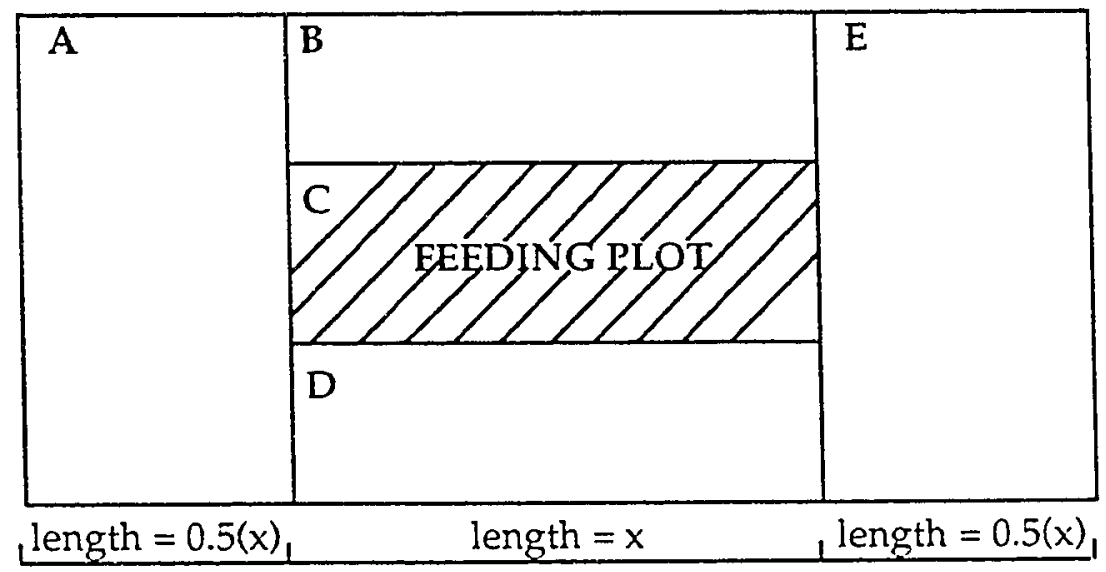

Figure 3. A-E area sampling design of six feeding plots in 1990. A feeding area was composed of five zones, $A-E$. The feeding plot, zone $C$, was that location heavily foraged by a flock of sanderling, whereas zones A, B, D, and $E$ were nonforaged locations surrounding $C$. Zone $D$ was lower tidally than zone $C$, and zone $B$ was higher tidally than zones $D$ or $C$. A zone's length and width were determined by the size of plot sanderling made while foraging; B, C, and D were the same width and length; $A$ and $E$ were three times the width, but half the length of zone $C$. 


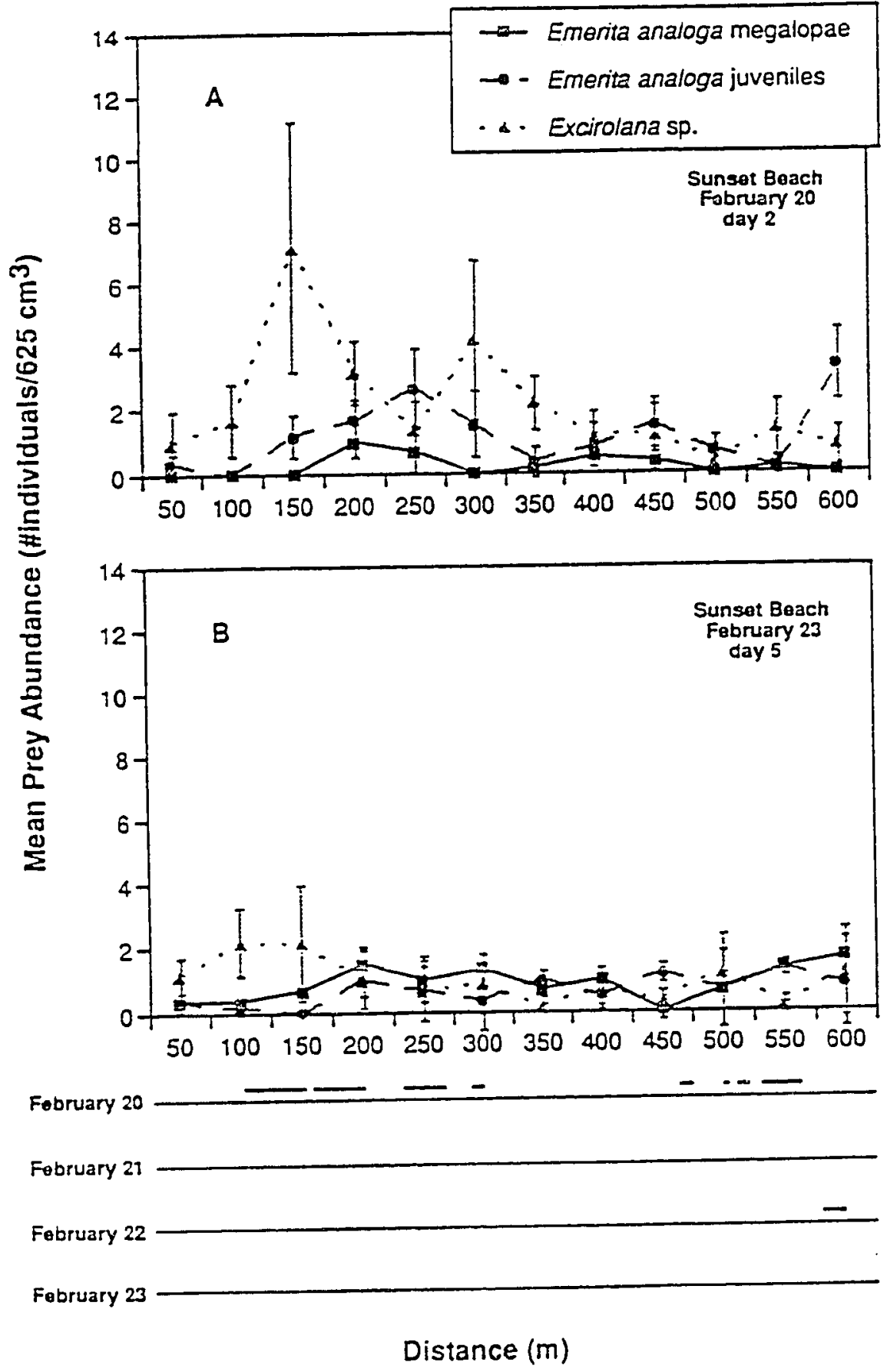

Figure 4, A - F. Mean prey abundances ( \pm SE) per $6 \times 50$ meter swath of beach $(n=6)$ are plotted against distance sampled along a beach during three, fiveday intervals. $A / B, C / D, E / F$ all represent day 2 and day 5 , respectively, of their sampling periods. Darkened lines underneath each figure, labeled with the date of observation, illustrate the location of sanderling feeding plots along the same distance of beach for a given day of observation or sampling. Figures $A / B$ and $E / F$ represent data collected from Sunset Beach, and figures $C / D$ represent Potrero Beach. 

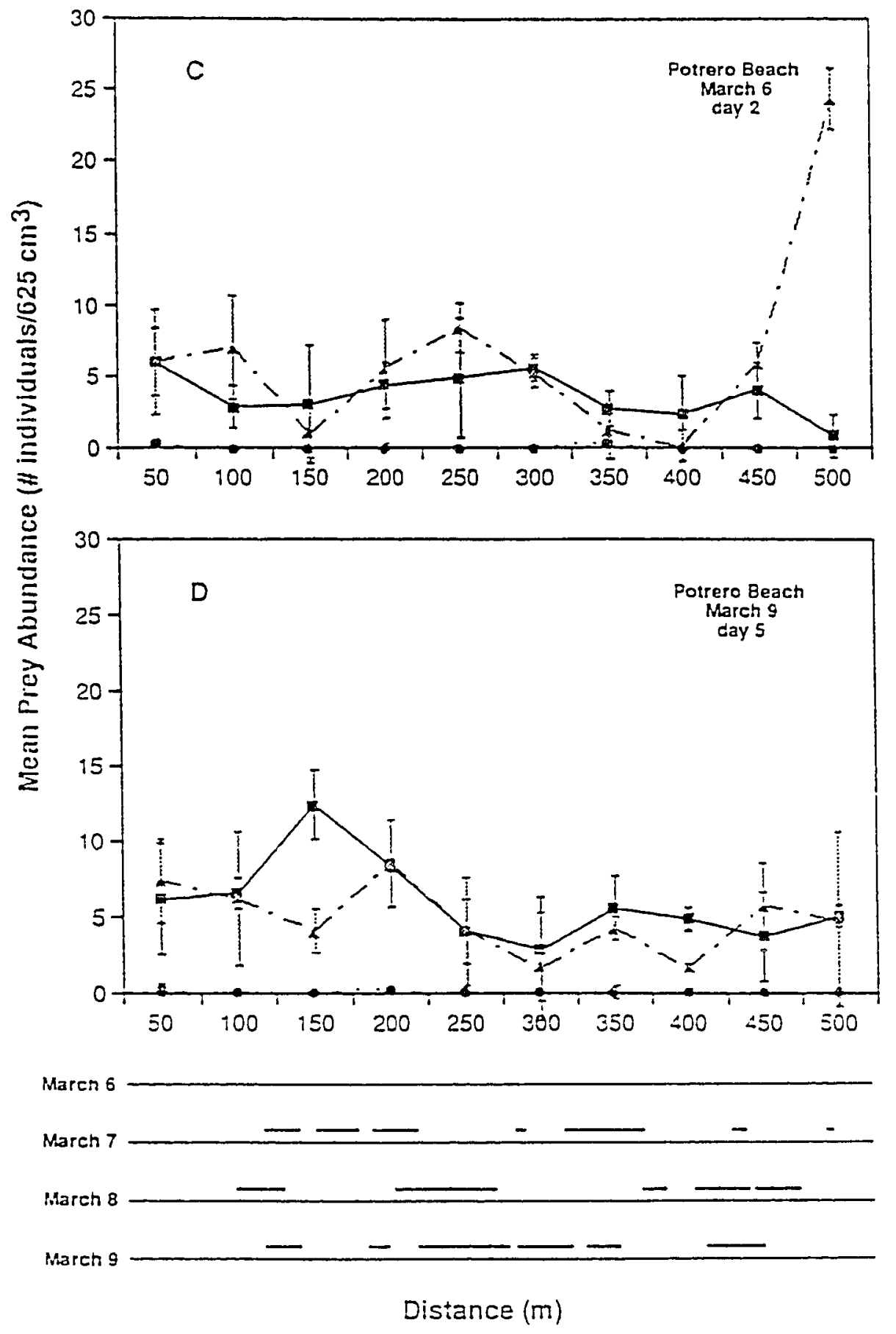

Figure $4, C \& D$. 


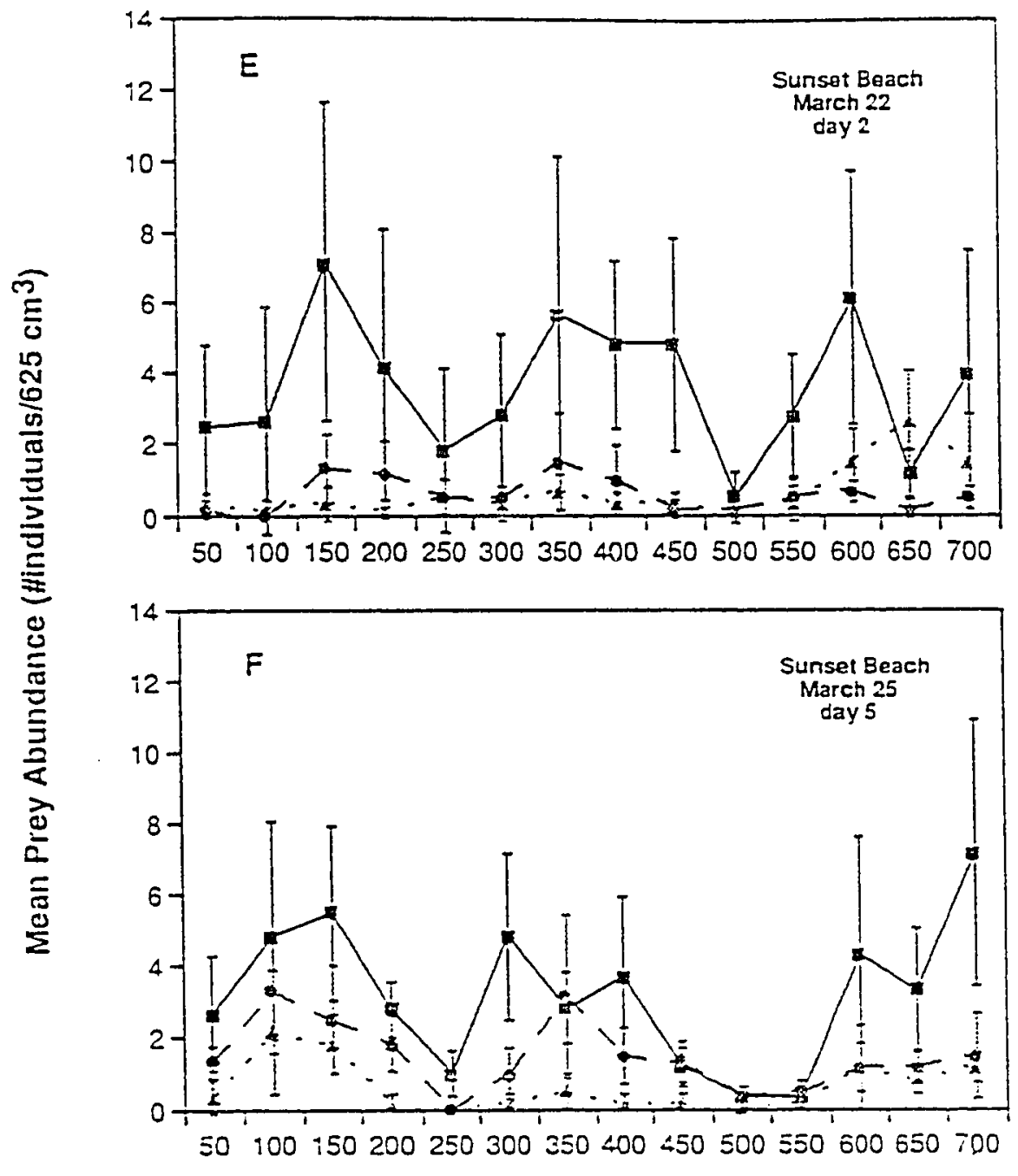

marchno

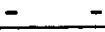

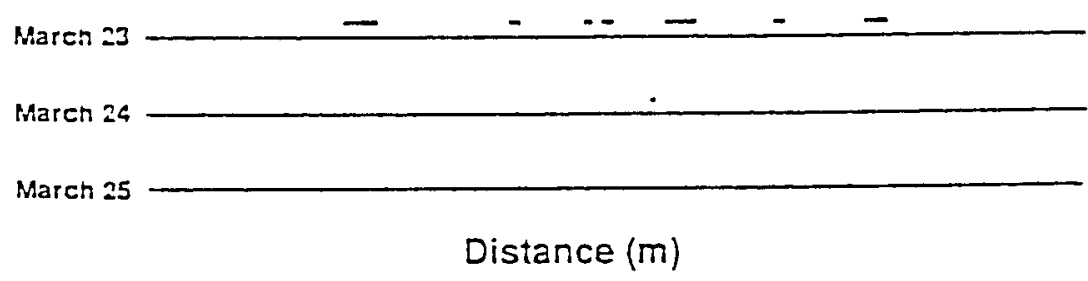

Figure 4, E \& F. 


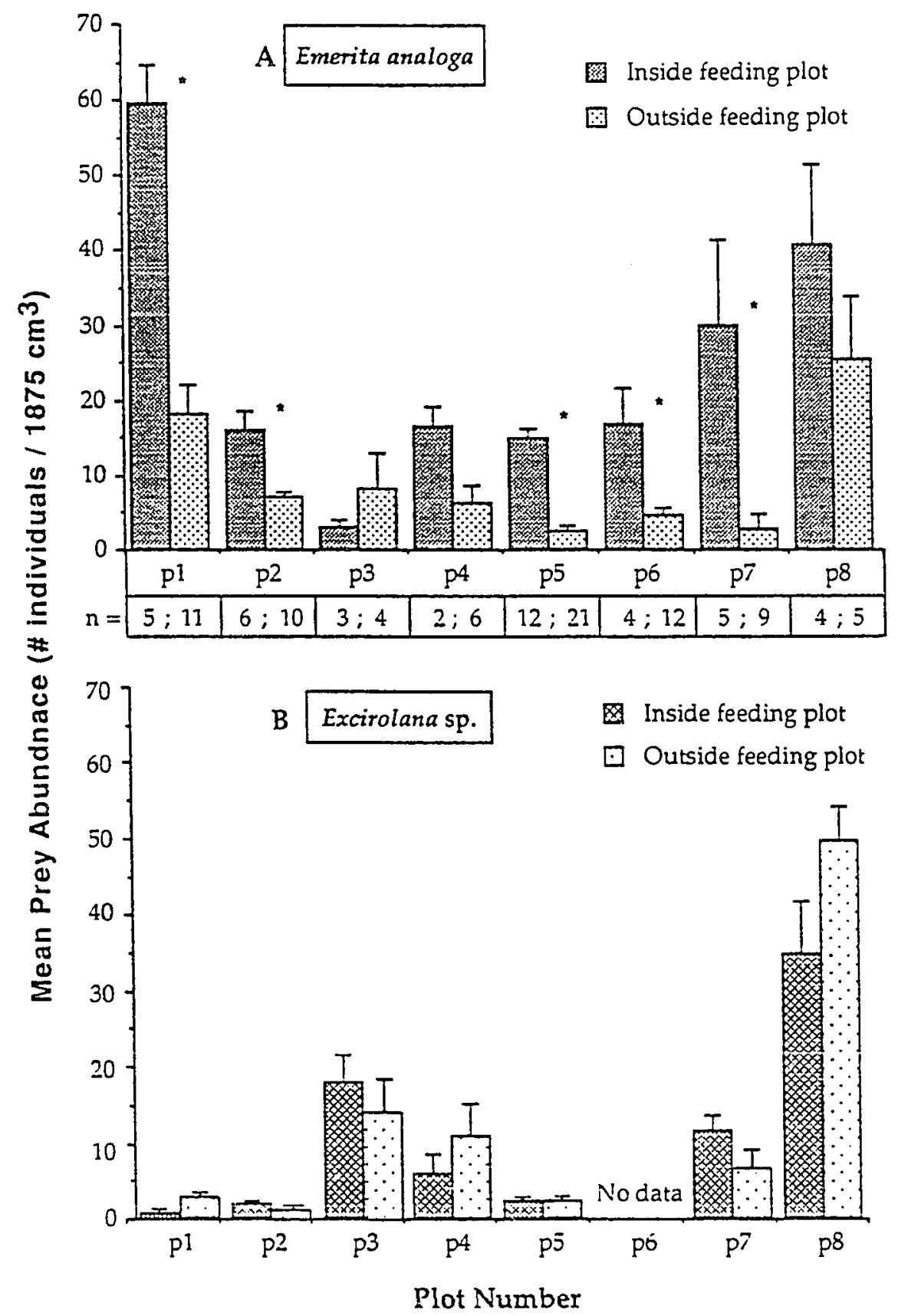

Figure $5, \mathrm{~A}$ and B. Mean abundance $( \pm \mathrm{SE}$ ) of Emerita analoga and Excirolana sp. inside and outside eight feeding plots in 1989. Mean abundances are reported per three cores $\left(1875 \mathrm{~cm}^{3}\right)$. Statistical tests used were either a MannWhitney (MW) or Student's t-test (St); $p$ values are as indicated. An asterik represents significant differences between inside and outside pry abundances for an individual plot. 


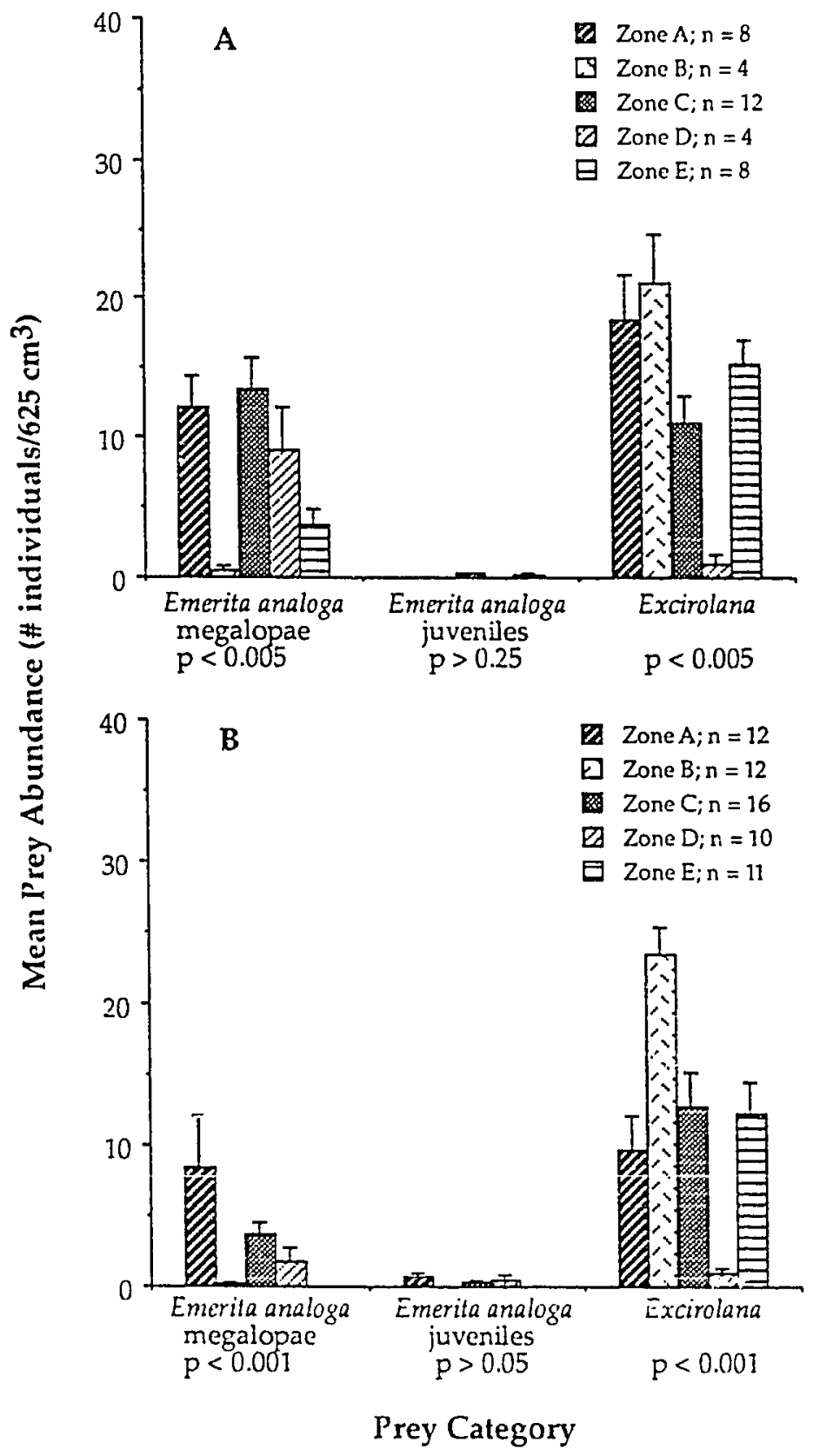

Figure 6, A - F. Six areas (graphs A - F) in which sanderling foraged were divided into five zones, $A-E$, for sampling. Zone $C$ was heavily foraged (e.g.. feeding plot), whereas zones A, B, D, and E were unforaged. Number of random cores taken in each zone of a given feeding area are indicated in legends. Significant differences in mean prey abundance among zones within a feeding area were determined using Kruskal-Wallis tests ( $p$ values as indicated). 


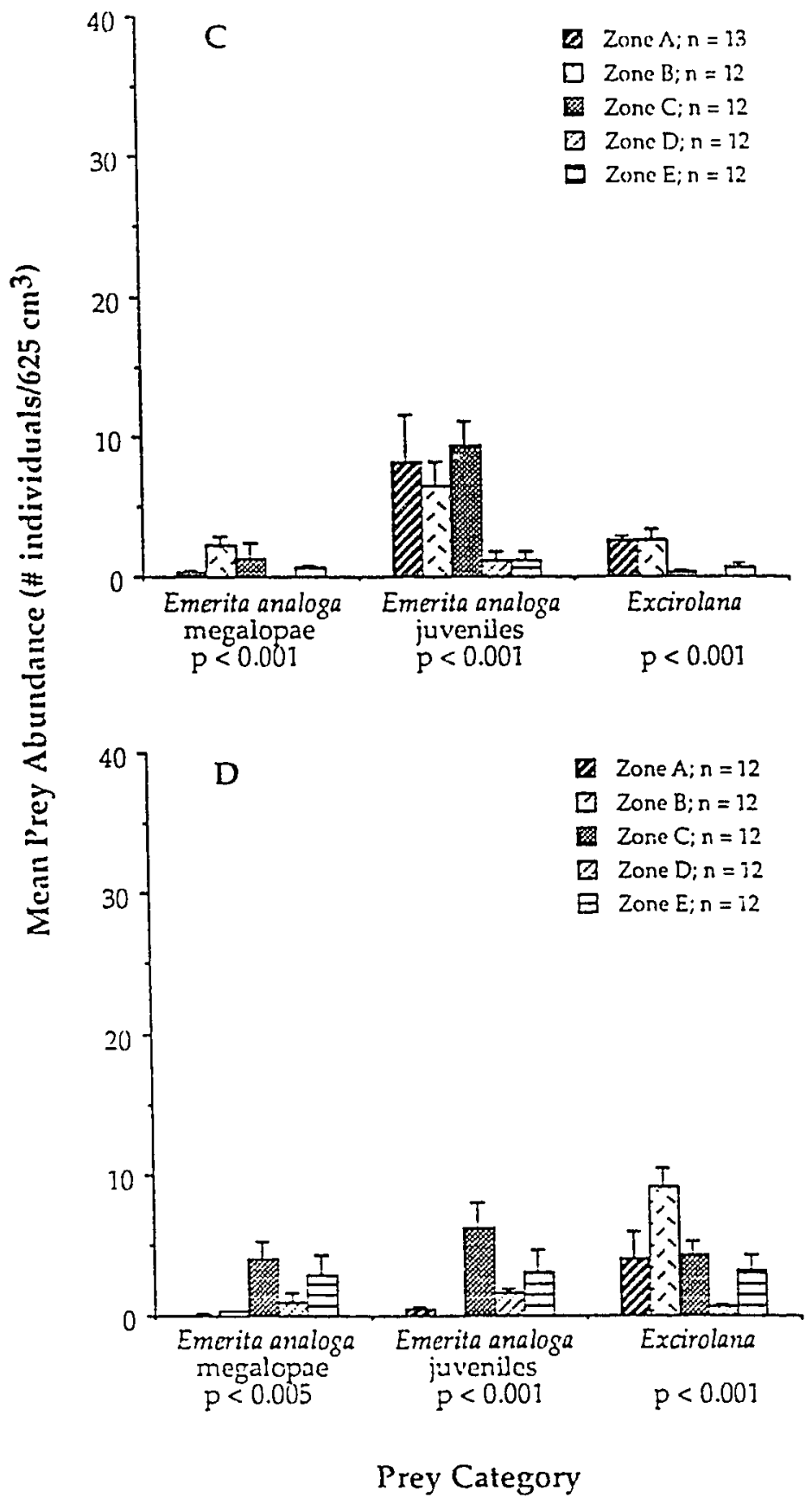

Figure $6, C \& D$. 


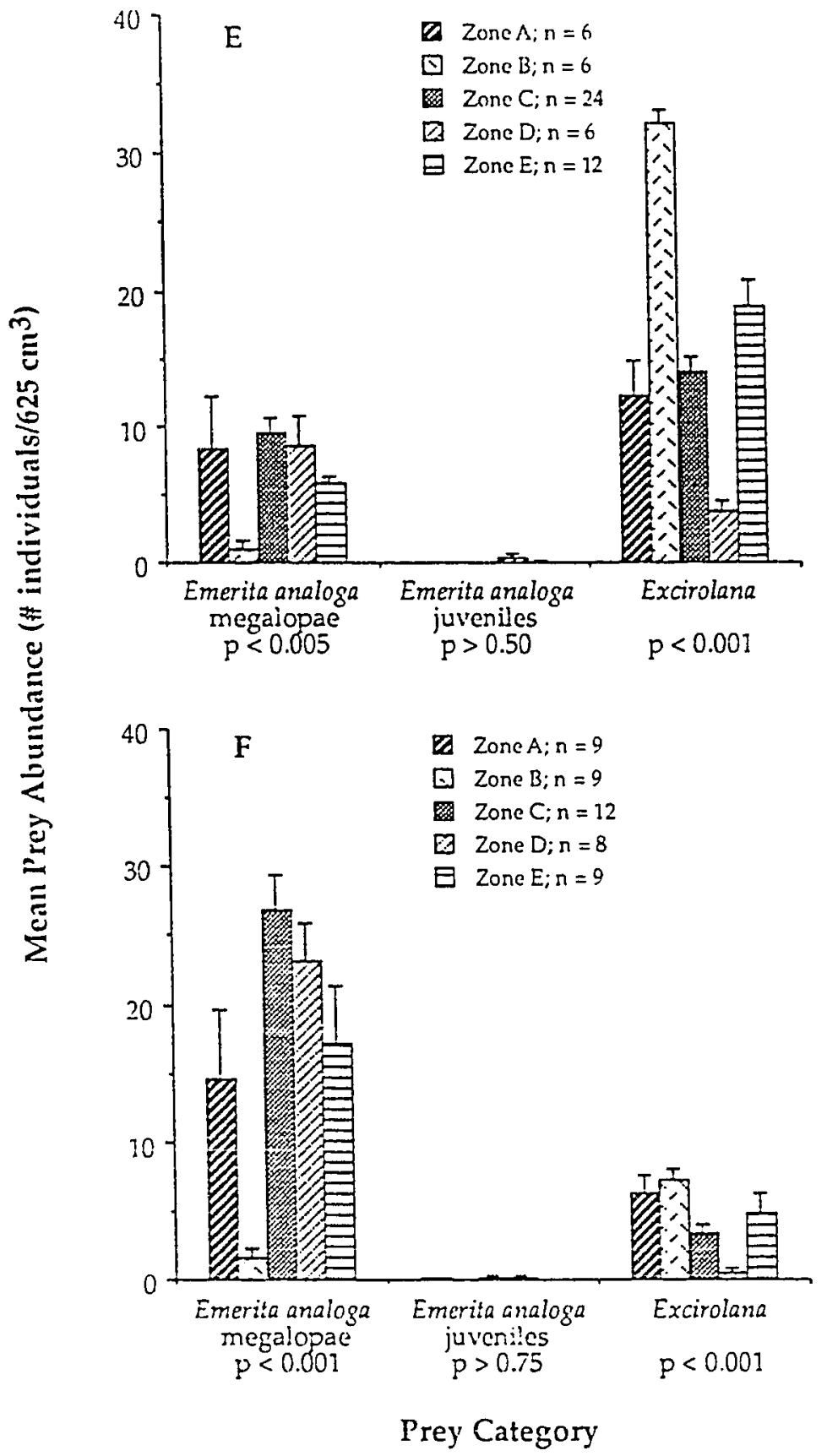

Figure 6, E \& F. 


\section{Exclusion Experiment}

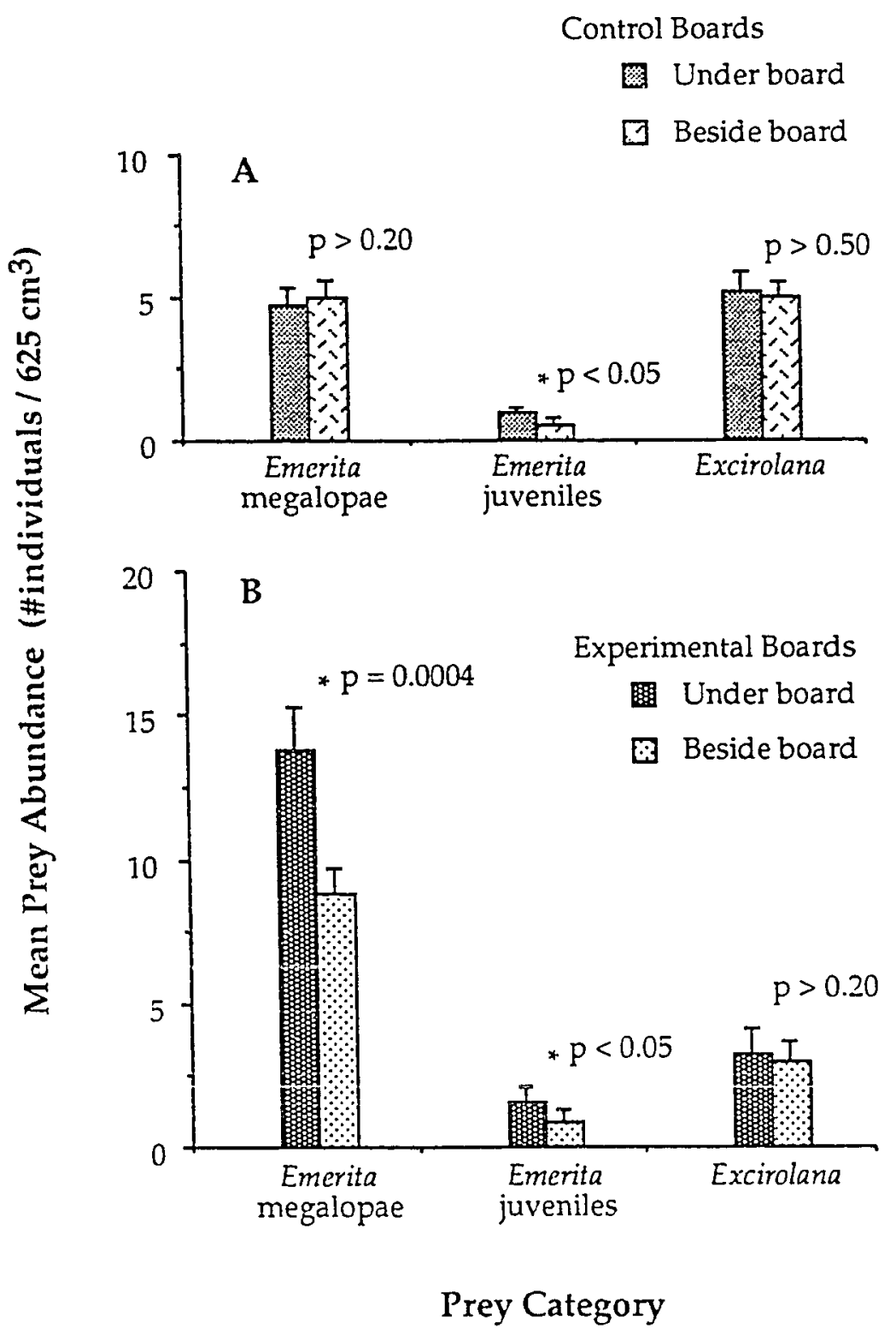

Figure 7, A\&B. Mean abundances ( $\triangle S E$ ) of Emerita analoga megalopae, juveniles and Excirolana sp. underneath and beside control $(A)$ and experimental (B) exclusion boards. Mean abundances of Emerita megalopae under and beside experimental boards were compared for differences using a paired t-test, whereas all other under vs. beside comparisons were made using Wilcoxon Signed-Rank tests. Significant differences are indicated with an asterik, and all $p$ values are reported in results. 


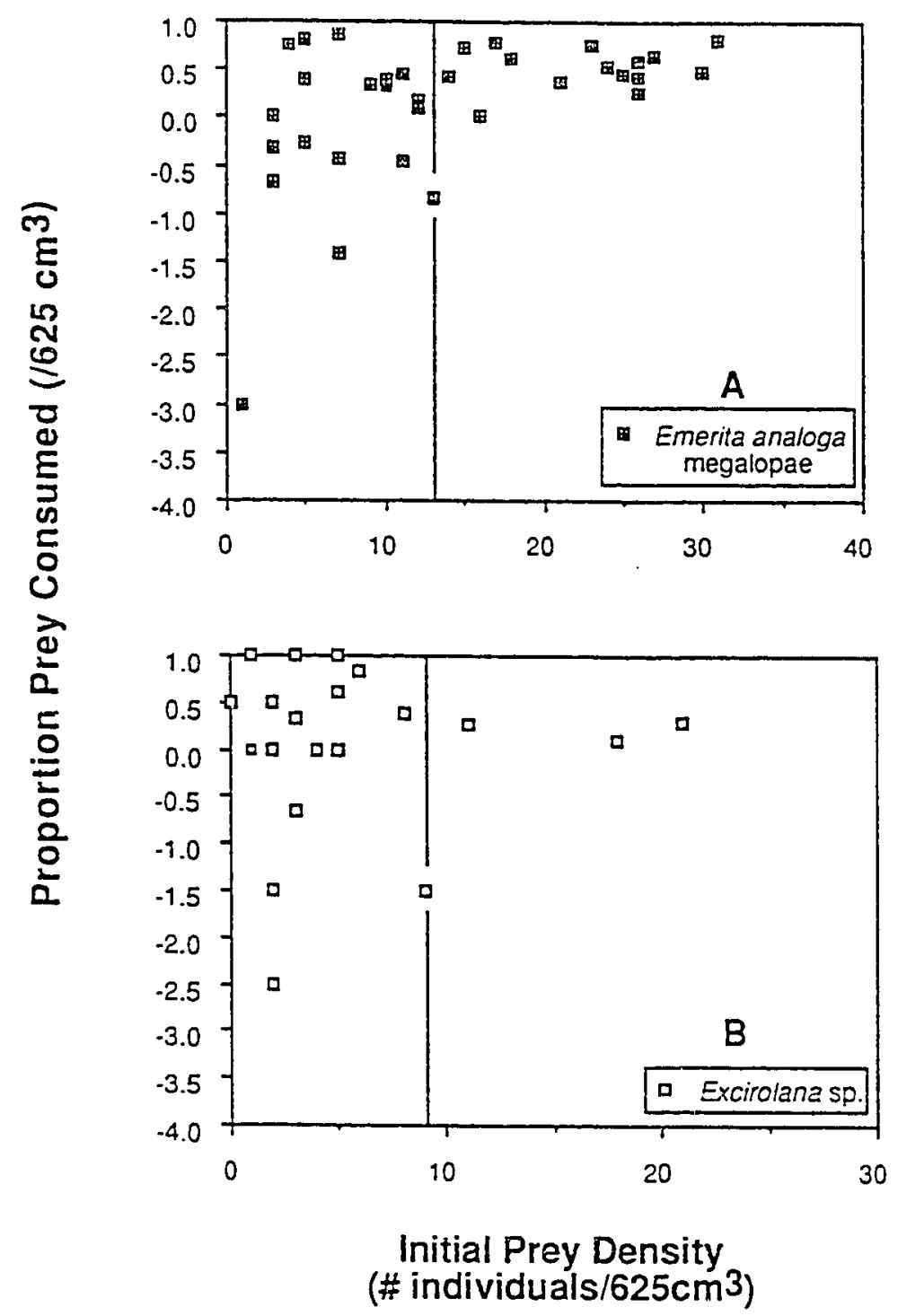

Figure 8, A\&B. The proportion of Emerita analoga megalopae (A) or Excirolana sp. (B) consumed by sanderling foraging in a flock. Each point represents under and beside board pairs from the exclusion experiment. Proportion of prey consumed is the difference between abundance under a board and beside the board divided by abundance under the board. Initial prey density is the abundance of E. analoga megalopae or Excirolana sp. in the core under a board. Solid lines were inserted at 13 Emerita $/ 625 \mathrm{~cm}^{3}$ and 9 Excirolana $/ 625 \mathrm{~cm}^{3}$ to indicate the initial prey density at which variation in the proportion decreased. 


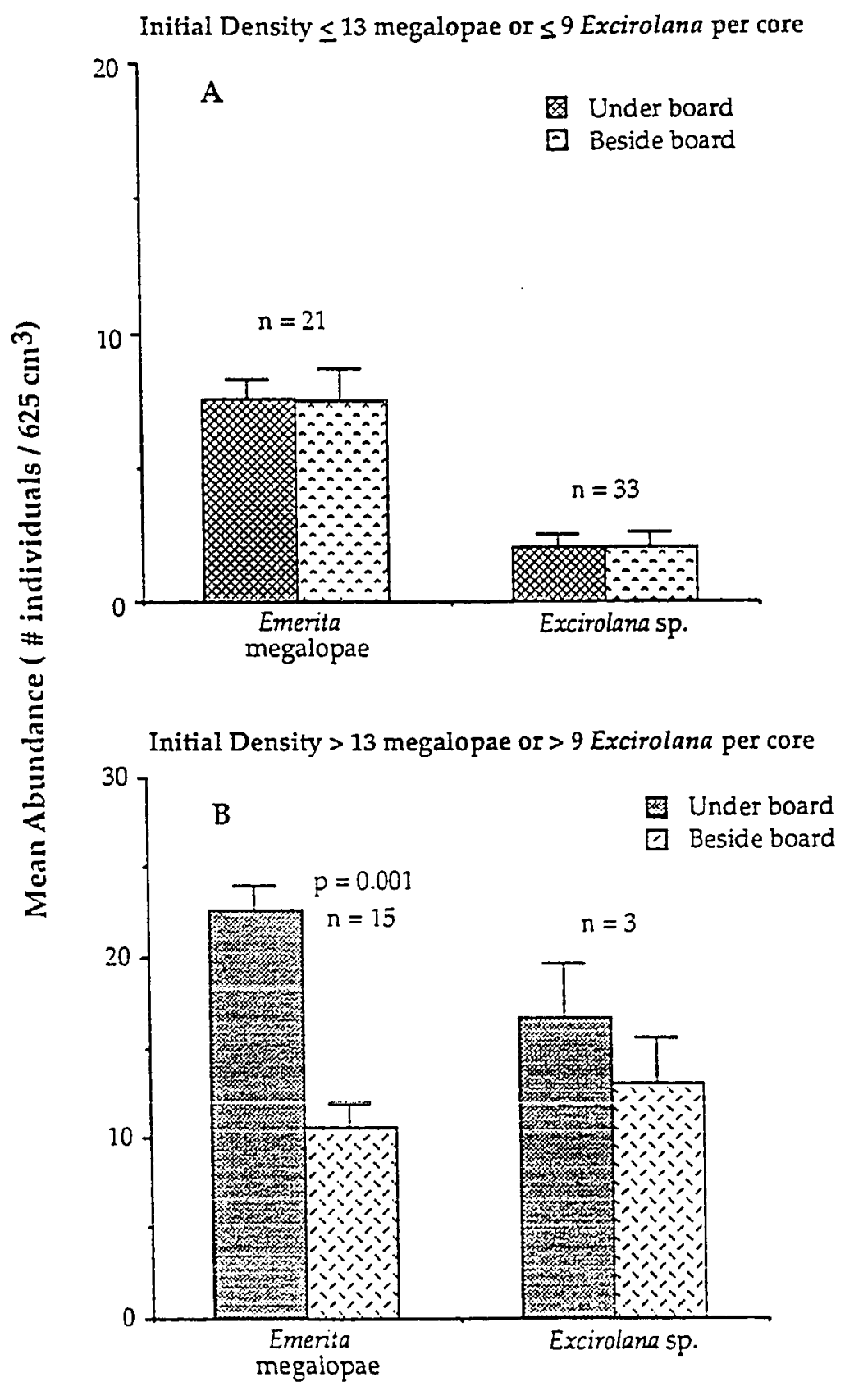

Prey Type

Figure 9, A\&B. Mean abundance of Emerita megalopae and Excirolana under and beside experimental boards when the initial density of prey (cores under boards) was $\leq 13$ megalopae or $\leq 9$ Excirolana $/ 625 \mathrm{~cm}^{3}(\mathrm{~A})$, and when initial density was $>13$ megalopae or $>9$ Excirolana $/ 625 \mathrm{~cm}^{3}(\mathrm{~B})$. 
Table 1. The index of dispersion, $I=\left(s^{2} / x\right)(n-1)$, of each prey type on the 2 nd and 5th days of sampling during a 5-day interval on Sunset and Potrero beaches in Monterey Bay. Day 2 and day 5 indices were compared to a Chi Squared critical value to test for distributional pattern of prey type. Sample sizes and probability level at which an index was significantly different from a random distribution (i.e. greater than one) are provided. An asterik indicates a randcin distribution, no asterik indicates a clumped distribution.

\begin{tabular}{|c|c|c|c|c|c|}
\hline \multicolumn{2}{|c|}{ Emerita Megalopae } & \multicolumn{2}{|c|}{ Enterita Juveniles } & \multicolumn{2}{|c|}{ Excirolana sp. } \\
\hline Day 2 & Day 5 & Day 2 & Day 5 & Day 2 & Day 5 \\
\hline \multicolumn{6}{|c|}{$\begin{array}{l}\text { Sunset Beach; February 20\&23, } 1990 \\
n=72\end{array}$} \\
\hline$I=97.36$ & 123.28 & 137.14 & 96.00 & 323.70 & 200.57 \\
\hline $\mathrm{p}<0.025$ & 0.001 & 0.001 & 0.05 & 0.001 & 0.001 \\
\hline \multicolumn{6}{|c|}{$\begin{array}{l}\text { Potrero Beach; March 6\&9, } 1990 \\
n=60\end{array}$} \\
\hline$I=243.29$ & 219.14 & 116.00 & $58.00^{*}$ & 637.96 & 239.09 \\
\hline$p<0.001$ & 0.001 & 0.001 & 0.75 & 0.001 & 0.001 \\
\hline \multicolumn{6}{|c|}{$\begin{array}{l}\text { Sunset Beach; March 22\&25, } 1990 \\
n=84\end{array}$} \\
\hline$I=648.74$ & 376.63 & 168.4 & 192.47 & 205.00 & 181.73 \\
\hline$p<0.001$ & 0.001 & 0.001 & 0.001 & 0.001 & 0001 \\
\hline
\end{tabular}


Table 2. Mean abundances ( $\pm \mathrm{SE}$ ) of Emerita analoga megalopae and juveniles, and Excirolana during 5-day sampling intervals on Sunset and Potrero Beaches. Differences in abundance for each prey type between day 2 and day 5 were tested using either Mann-Whitney (MW) or Student's t-test (St). Sample sizes and probalility levels at which significant differences occurred are provided.

\begin{tabular}{|c|c|c|c|c|c|c|}
\hline & \multicolumn{2}{|c|}{ Emerita Megalopae } & \multicolumn{2}{|c|}{ Emerita Juveniles } & \multicolumn{2}{|c|}{ Excirolana sp. } \\
\hline & Day 2 & Day 5 & Day 2 & Day 5 & Day 2 & Day 5 \\
\hline \multicolumn{7}{|c|}{$\begin{array}{l}\text { Sunset Beach; February 20-23, } 1990 \\
n=72\end{array}$} \\
\hline $\bar{x}=$ & 0.24 & 0.88 & 1.18 & 0.67 & 2.13 & 1.17 \\
\hline \multirow[t]{2}{*}{$\mathrm{SE}=$} & 0.07 & 0.15 & 0.18 & 0.11 & 0.34 & 0.21 \\
\hline & \multicolumn{2}{|c|}{$\mathrm{MW} ; \mathrm{p}<0.001$} & \multicolumn{2}{|c|}{$M W ; p>0.05$} & \multicolumn{2}{|c|}{$M W ; p=0.02$} \\
\hline \multicolumn{7}{|c|}{$\begin{array}{l}\text { Potrero Beach; March 6-9, } 1990 \\
n=60\end{array}$} \\
\hline $\bar{x}=$ & 3.63 & 5.92 & 0.67 & 0.33 & 6.45 & 4.80 \\
\hline \multirow{2}{*}{$S E=$} & 0.50 & 0.61 & 0.05 & 0.02 & 1.08 & 0.57 \\
\hline & \multicolumn{2}{|c|}{ St; $p=0.004$} & \multicolumn{2}{|c|}{$M W ; p>0.50$} & \multicolumn{2}{|c|}{$M W ; p>0.50$} \\
\hline \multicolumn{7}{|c|}{$\begin{array}{l}\text { Sunset Beach; Miarch 22-25, } 1990 \\
n=84\end{array}$} \\
\hline $\bar{x}=$ & 3.86 & 3.20 & 0.60 & 1.51 & 0.67 & 0.67 \\
\hline \multirow{2}{*}{$\mathrm{SE}=$} & 0.60 & 0.42 & 0.12 & 0.20 & 0.14 & 0.13 \\
\hline & \multicolumn{2}{|c|}{$M W ; p>0.50$} & \multicolumn{2}{|c|}{$\mathrm{MW} ; \mathrm{p}<0.001$} & \multicolumn{2}{|c|}{ St; $p=0.95$} \\
\hline
\end{tabular}


Table 3. Results of Fligner-Policello multiple comparison tests. Comparisons of mean abundances between feeding plot $(C)$ and surrounding zones (A, B, $D, \& E$ ) within a sanderling feeding area. NS indicates no significant differences between zones; a < or > symbol indicates which zone had significantly less (or more) prey within it after foraging ( $\mathrm{p}<0.05$ ).

\begin{tabular}{|c|c|c|c|c|c|}
\hline \multicolumn{6}{|c|}{ A) Emerita analoga megalopae: } \\
\hline & A vs. $C$ & $B$ vs. $C$ & D vs. C & E vs. C & $A, B, D, E$ vs. $C$ \\
\hline \multicolumn{6}{|c|}{ plot: } \\
\hline 1 & ns & $<$ & ns & $<$ & $<$ \\
\hline 2 & ns & $<$ & $<$ & $<$ & $<$ \\
\hline 3 & ns & $<$ & ns & ns & ns \\
\hline 4 & $<$ & $<$ & $<$ & ns & $<$ \\
\hline 5 & ns & $<$ & ns & $<$ & $<$ \\
\hline \multirow[t]{3}{*}{6} & $<$ & $<$ & ns & $<$ & $<$ \\
\hline & B) Ennerit & $\operatorname{aloga~jux}$ & les: & & \\
\hline & A vs. C & B vs. C & D vs. C & E vs. C & $A, B, D, E$ vs. $C$ \\
\hline 2 & ns & ns & ns & ns & ns \\
\hline 3 & ns & ns & $<$ & $<$ & $<$ \\
\hline \multirow[t]{3}{*}{4} & $<$ & $<$ & $<$ & $<$ & $<$ \\
\hline & C) Exciro & sp.: & & & \\
\hline & A vs. C & B vs. C & D vs. C & Evs. C & $A, B, D, E$ vs. $C$ \\
\hline \multicolumn{3}{|c|}{ plot: } & $<$ & & \\
\hline 2 & ns & $>$ & $<$ & ns & ns \\
\hline 3 & $>$ & ns & $\mathrm{ns}$ & ns & ns \\
\hline 4 & ns & $>$ & $<$ & ns & $<$ \\
\hline 5 & ns & $>$ & $<$ & $>$ & ns \\
\hline 6 & $>$ & $>$ & $<$ & ns & ns \\
\hline
\end{tabular}

